\title{
Highly Functionalized $\beta$-Enamino Esters via C-C Coupling Reactions of Lithium Enolates of Protected Glycine Esters and Isothiocyanates
}

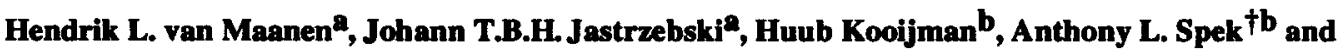 \\ Gerard van Koten $*$ a \\ a Debye Institute, Department of Metal-Mediated Synthesis, Utrecht University, Padualaan 8, 3584 CH Utrecht, The Netherlands \\ b Bijvoet Center for Biomolecular Research, Department of Crystal- and Structural Chemistry, Utrecht University, Padualaan 8 , \\ 3584 CH Utrecht, The Netherlands
}

\begin{abstract}
Lithium enolates of N,N-diprotected glycine esters were reacted with isothiocyanates, affording $\mathrm{E}_{2} \mathrm{O}$ coordinated lithium thiolates $\mathrm{R}^{1} \mathrm{~N}(\mathrm{H})-\mathrm{C}(\mathrm{SLi})=\mathrm{C}\left(\mathrm{NR}_{2}\right)-\mathrm{COOEt}\left(2 \mathrm{a}: \mathrm{R}_{2}=-\mathrm{Si}\left(\mathrm{CH}_{3}\right)_{2}\right.$ $\mathrm{CH}_{2} \mathrm{CH}_{2}-\mathrm{Si}\left(\mathrm{CH}_{3}\right)_{2}-\mathrm{R}^{1}=\mathrm{Ph} ; 2 \mathrm{~b} ; \mathrm{R}_{2}=-\mathrm{Si}\left(\mathrm{CH}_{3}\right)_{2}-\mathrm{CH}_{2} \mathrm{CH}_{2}-\mathrm{Si}\left(\mathrm{CH}_{3}\right)_{2-} ; \mathrm{R}^{1}=-\mathrm{CH}_{2} \mathrm{Ph} ; 2 \mathrm{ct} \mathrm{R}=\mathrm{Et}$; $\mathbf{R}^{1}=\mathrm{Ph}$ ), in which the carboxyl oxygen atom is coordinated to lithium. Thiolate $2 \mathrm{a}$ was shown to be dimeric in the solid state by $\mathbf{X}$-ray crystal structure determination.

Hydrolysis of $\mathrm{N}$-protected lithium thiolates $2 \mathrm{and} 2 \mathrm{~b}$ afforded 2-aminothiomalonamic esters 3a and 3b, resulting from $\mathrm{C}$-protonation. $\mathrm{N}, \mathrm{N}$-diethyl substituted lithium thiolate $2 \mathrm{c}$ afforded mainly [2-(N,Ndiethyl)amino-3-mercapto]-B-enamino ester 3c', the S-protonated product, which is in slow equilibrium with the $C$-protonated tautomer. Ring closure to 4-thioxo-p-lactams was unsuccessful. Highly functionalized 3-methylthio- $\beta$-enamino esters were obtained via S-alkylation of the lithium thiolates 2 with iodomethane.
\end{abstract}

\section{INTRODUCTION}

In the past decades, much research has been devoted to the development of synthetic routes to $\beta$-lactam antibiotics. However, completely synthetic routes to penicillins cephalosporins have not found widespread application ${ }^{1}$, due to problems encountered in the synthesis of $\beta$-lactam precursors with a $\mathbf{C}(4)$-sulphur substituent and the availability of intermediates from biological sources ${ }^{2}$. Starting from thioimidates, both the classical Staudinger reaction ${ }^{3}$ and the modified procedure using acid chlorides 4 commonly produce trans-substituted $\beta$ -

* To whom correspondence should be aldressed

$†$ To whom correspondence pertaining to crystal structural dan should be addreased 
lactams, 5,6 whereas the cis-configuration is a prerequisite for antibacterial activity 1 . An alternative synthetic route is the condensation reaction of ester enolates and imines ${ }^{7}$. This route offers control of the diastereoselectivity of the reaction through the choice of the metal counterion. However, 4-alkylthio substituted $\beta$-lactams appear not to be accessible via this ester enolate-imine condensation route ${ }^{7 \mathrm{a}}$.

4-Thioxo- $\beta$-lactams, which were first obtained via thermolysis ${ }^{8}$ or photolysis ${ }^{9}$ of sulfoxides of trans-4alkylthio- $\beta$-lactams, were recognized as possible penem and cephem precursors. Furthermore, these compounds have been converted into 4-alkylidene-2-azetidinones ${ }^{10}$, azetidine-2,4-diones ${ }^{10}$ and 4-spirocyclopropyl-2azetidinones $^{11}$. Several miscellaneous routes to 4 -thioxo- $\beta$-lactams have been published, e.g. a [2+2] cycloaddition of thioketenes and isothiocyanates ${ }^{12}$, photocyclisation of $\mathrm{N}$-acetyl-thiocarbamates ${ }^{13}$ or selective thionation of azetidine-2,4-diones ${ }^{13}$. Recently, the synthesis of 4-thioxo- $\beta$-lactams from ester enolates has been reported, by reacting them with isothiocyanates instead of imines ${ }^{14}$. The intermediate thiomalonamic esters are cyclized to 4-thioxo- $\beta$-lactams, that are readily converted to 4-acetylthio-2-azetidinones. However, the cyclisation gave poor yields ( $<25 \%$ ) of 3-alkyl- $\beta$-lactams when monosubstituted ester enolates were employed. The reported 3,3-dialkyl- $\beta$-lactams are merely interesting from a scientific point of view.

As the biologically active cephems and penems possess an amidofunction at the 3-position of the $\beta$-lactam ring ${ }^{15}$, we selected suitably protected glycine ester enolates as the starting compounds in the C-C coupling reaction with isothiocyanates. Not only the lithium enolates, but also the chlorozinc and dimethylaluminum enolates of protected glycine esters were studied. We have previously demonstrated ${ }^{16}$, that these enolates combine excellent diastereoselectivity and a high reactivity in the ester enolate-imine condensation reaction.

\section{RESULTS \& DISCUSSION}

$C$-C coupling Reactions. The lithium enolate of ethyl ([2,2,5,5-tetramethyl-1-aza-2,5-disila]cyclopentyl)acetate ${ }^{17}$ 1a was reacted with phenyl isothiocyanate in $\mathrm{Et}_{2} \mathrm{O}$ at $-78{ }^{\circ} \mathrm{C}$ to afford lithium thiolate $2 \mathrm{a}$ (scheme 1). Recrystallisation from $\mathrm{Et}_{2} \mathrm{O}$ /pentane afforded $2 \mathrm{a}$ as light yellow disk-shaped crystals, in $80 \%$ yield. One equivalent of $\mathrm{Et}_{2} \mathrm{O}$ was incorporated in the crystals, as was evidenced by ${ }^{1} \mathrm{H}$ and ${ }^{13} \mathrm{C}$ NMR and by $\mathrm{X}$-ray diffraction (vide infra). Benzyl isothiocyanate reacted similarly with the lithium enolate of 1 a to give the C-C coupled product $\mathbf{2 b}$ in a good yield ${ }^{18}$.

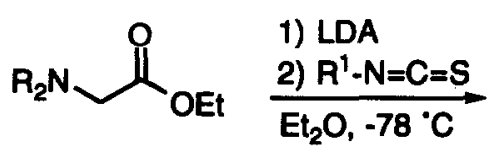

1a: $\mathrm{R}_{2}=-\mathrm{Me}_{2} \mathrm{SiCH}_{2} \mathrm{CH}_{2} \mathrm{SiMe}_{2}-$ 1b: $R=E t$

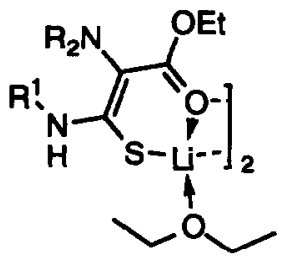

scheme 1 2a: $R^{1}=P h$, $\mathrm{R}_{2}=-\mathrm{Me}_{2} \mathrm{SiCH}_{2} \mathrm{CH}_{2} \mathrm{SiMe}_{2}-$ 2b: $\mathbf{R}^{1}=\mathrm{PhCH}_{2}$, $\mathrm{R}_{2}=-\mathrm{M \theta}_{2} \mathrm{SiCH}_{2} \mathrm{CH}_{2} \mathrm{SiM \theta}_{2}-$ 2c: $R^{1}=P h, R=E t$ 
The lithium enolate of ethyl (N,N-diethyl)glycinate $1 \mathrm{~b}$ reacts only at elevated temperatures, because it is stabilized by intramolecular coordination ${ }^{16 e}$. The reaction with phenylisothiocyanate was therefore performed in refluxing THF and in the absence of diisopropylamine, since this adds readily to phenylisothiocyanate to give the corresponding thiourea ${ }^{19}$. Prior to the reaction, the diisopropylamine-free enolate was isolated by evacuating to dryness in vacuo. Alternatively, the lithium enolate was generated in situ by deprotonation with LiHMDS, because hexamethyldisilazane is not nucleophilic enough to react with phenyl isothiocyanate. Irrespective of the method, the conversion of the $\mathrm{C}-\mathrm{C}$ coupling reaction was almost quantitative. Repeated crystallisation from $\mathrm{Et}_{2} \mathrm{O}$ afforded the $\mathrm{Et}_{2} \mathrm{O}$ adduct of the lithium thiolate $2 \mathrm{c}$ as yellow disk-shaped crystals in $76 \%$ yield.<smiles>CCOC1=C(N2[Si](C)(C)CC[Si]2(C)C)C(Nc2ccccc2)=C(C)[Al](C)(C)O1</smiles><smiles>CCO[R5](C)(C)C(C)(C)Cl</smiles>

2e: $97 \%$<smiles>CCOC(=O)C1=C(Nc2ccccc2)S[Al](C)(C)O[Si]1(C)C</smiles>

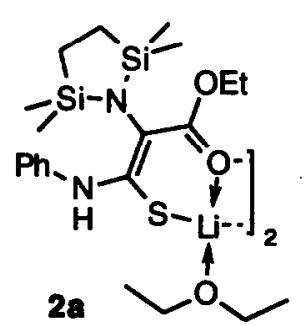<smiles>CCOCCC(C)C(C)C(C)(Cl)Cl</smiles>

2d: $90 \%$<smiles>[Y][Z6]1(Cl)C=C(Nc2ccccc2)C(N2[Si](C)(C)CC[Si]2(C)C)=C(OCC)O1</smiles><smiles>[Y][Z20]1(Cl)OC(=O)C(N2[Si](C)(C)CC[Si]2(C)C)=C(Nc2ccccc2)S1</smiles>

scheme 2

The reaction of the chlorozinc enolate of $1 \mathrm{a}$ with phenyl isothiocyanate was so slow, that decomposition of the enolate ${ }^{16 e, 20}$ became competitive. To avoid thiourea formation, the enolate was generated with LHMDS instead of LDA. The dimethylaluminium enolate of $1 \mathrm{a}$ did not react at all, even though $10 \%$ excess of $\mathrm{Me}_{2} \mathrm{AlCl}$ was used in the transmetallation step ${ }^{16 c}$. Transmetallation of $2 \mathrm{a}$ with zinc chloride or dimethylaluminum chloride in $\mathrm{Et}_{2} \mathrm{O}$ afforded the corresponding chlorozinc (2d) and dimethylaluminum (2e) thiolates in almost quantitative yields (scheme 2). The dimethylaluminum compound $2 e$ crystallized readily from pentane as yellow disk-shaped crystals, containing no $\mathrm{Et}_{2} \mathrm{O}$. The chlorozinc thiolate $2 \mathrm{~d}$ could not be obtained in a crystalline form. Compounds 2a-e were characterized by ${ }^{1} \mathrm{H}$ and ${ }^{13} \mathrm{C}$ NMR, cryoscopy and $\mathrm{IR}$. The solid state structure of $2 \mathrm{a}$ was determined via an $\mathrm{X}$-ray crystal structure determination.

\section{Molecular Structure of $2 a$.}

Crystals of 2a, suitable for $\mathrm{X}$-ray crystal structure determination, were obtained by careful recrystallisation from $\mathrm{Et}_{2} \mathrm{O}$. The molecular structure of $2 \mathrm{a}$ is shown in figure 1 , while selected bond distances and angles are given 
in table 1. Compound $2 \mathrm{a}$ is a dimer bridged by the carboxyl oxygen atom. The organic moiety acts as a rigid, planar $(\mathrm{S}, \mathrm{O})$-bidentate ligand to lithium, with a bite angle of $91.1(2)^{\circ}$. Noteworthy, $\mathrm{N}(1)$ is $s \mathrm{p}^{2}$ hybridized, as the sum of angles for $N(1)$ is $360^{\circ}$ within experimental error. The shortened $C(7)-N(1)$ bond length of $1.371(4) \AA$ and the coplanarity of the plane of the $N(1)$ substituents with the delocalized system of $S-C(7)-C(8)-C(15)-O(1)$ shows that the $\mathrm{p}_{\mathrm{z}}$-orbital of $\mathrm{N}(1)$, and possibly also the phenyl ring, is conjugated with this delocalized system. The tilt angle of $35.30(13)^{\circ}$ between the planes of the delocalized system and the phenyl ring might be a result of the crystal packing.

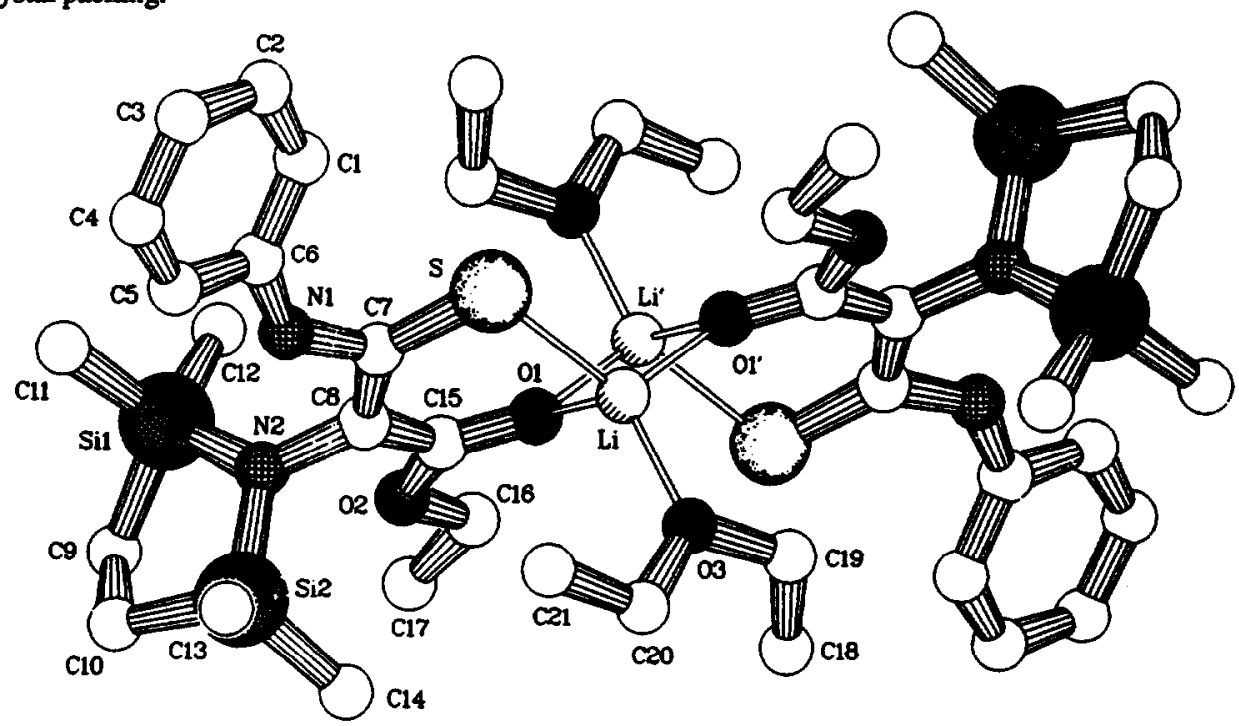

Figure 1: Molecular structure of 2a, PLUTON drawing showing the adopted numbering scheme. :

Table 1: Selected Geometrical Data for $2 a$

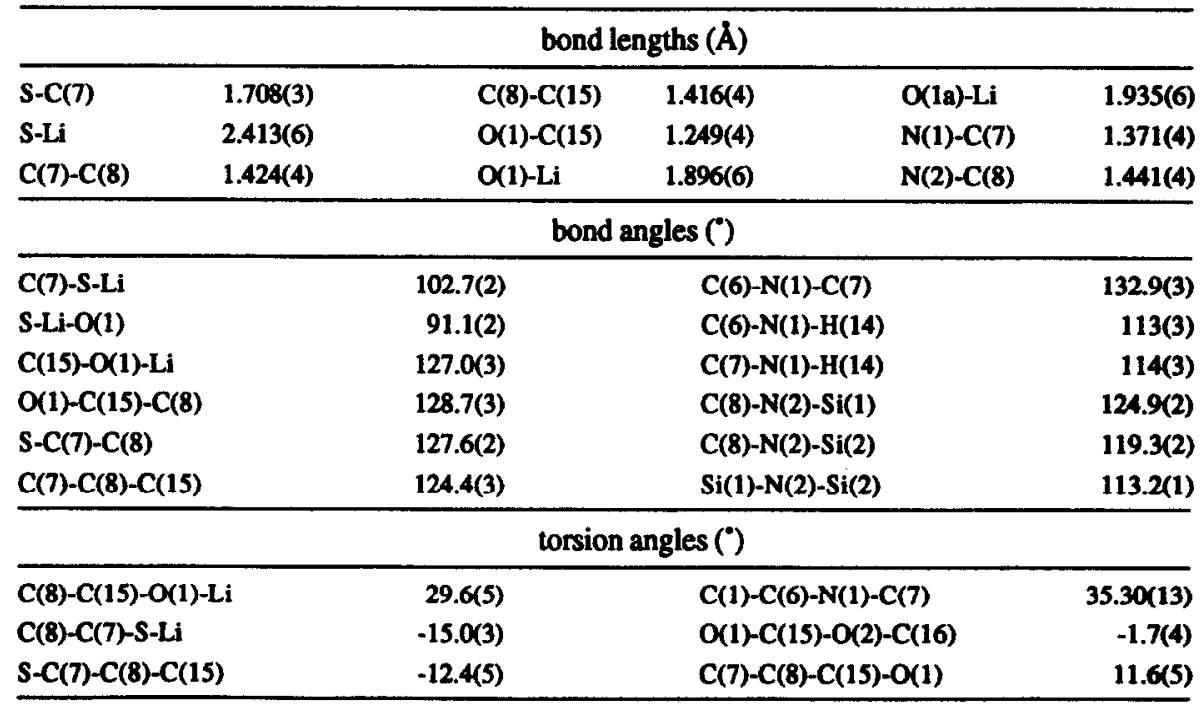


The other nitrogen atom $\mathrm{N}(2)$ is also $\mathrm{sp}^{2}$ hybridized. However, it is not part of the aforementioned delocalized system, because this is nearly perpendicular to the $\mathrm{p}_{\mathrm{z}}$-orbital of $\mathrm{N}(2)$. The $\mathrm{sp}^{2}$ hybridisation is not uncommon for nitrogen atoms bound to two silicon atoms. ${ }^{16 a}$ It has been generally accepted that the overlap of the filled $\mathrm{p}_{\mathrm{z}}$ orbital of $\mathrm{N}(2)$ with empty, low-lying orbitals on silicon is a stabilizing factor, although the nature of these orbitals ( $3 \mathrm{~d}$ or $\pi^{*}$ ) is the subject of discussion 21 .

The X-ray structure of 2a represents the first example of a thiomalonamic ester metal complex. The structure resembles that of lithium acetylacetonate ( $\mathrm{Li}[\mathrm{acac}])$ and lithium ethyl acetylacetate. The $\mathrm{Li}-\mathrm{O}$ distance of $1.896(6) \AA$ in $2 \mathrm{a}$ is short (comparable with $\mathrm{CH}_{3} \mathrm{COOLi}$ : $1.895 \AA^{22}$ ); in $\mathrm{Li}(\mathrm{acac})^{23}$, the $\mathrm{Li}-\mathrm{O}$ distances are in the range of $1.923(6)$ to $1.967(6) \AA$. The $O(1)-C(15)$ distance of $1.249(4) \AA$ is close to the value found for the isolated $\mathrm{C}=\mathrm{O}$ double bond in a lithium aldolate ${ }^{24}(1.22 \AA)$, in which the oxygen atom is coordinating to lithium. On the other hand, the $\mathrm{C}-\mathrm{O}$ single bond lengths in lithium ester enolates ${ }^{25}(1.30-1.32 \AA)$ are much longer. The $\mathrm{C}(7)-\mathrm{C}(8)$ and $\mathrm{C}(8)-\mathrm{C}(15)$ bonds in $2 \mathrm{a}(1.424(3)$ and 1.416(4) $\AA$ ) are somewhat longer than in Li(acac) (1.398(9) and $1.400(9) \AA$ ), whereas the $\mathrm{O}(1)-\mathrm{C}(15)$ distance of $1.249(4) \AA$ in $2 \mathrm{a}$ is slightly smaller than the corresponding values of $\mathrm{Li}(\mathrm{acac})^{23}(1.256(8)$ and $1.269(8) \AA)$. Therefore, the $\mathrm{C}=\mathrm{O}$ bond of $2 \mathrm{a}$ has a higher bond order than the $\mathrm{C}=\mathrm{O}$ bonds of $\mathrm{Li}(\mathrm{acac})$, and $\mathrm{O}(1)$ carries less negative charge. However, as both in $2 \mathrm{a}$ and in $\mathrm{Li}(\mathrm{acac})$ these bonds are significantly longer than the corresponding distances in the ionic 15-crown-5 complexed sodium ethylacetylacetonate 26 (1.20 $\AA$ for the ester carboxyl bond, 1.35 and $1.39 \AA$ for the $C-C$ bonds), they possess a significant amount of covalent character.

The Li-S distance of 2.413(6) $\AA$ is in the typical range for lithium thiolates. ${ }^{27}$ The C-S bond length of $1.708(3) \AA$ is however relatively short, as the corresponding value in lithium thiolates ranges from 1.751(3) $\AA$ for arylthiolates $27 a-d$ to $1.890 \AA$ for sterically hindered alkylthiolates. ${ }^{27 e, f}$ It is similar to the $1.703 \AA$ for the C-S bond in $\mathrm{Li}-\mathrm{S}-\mathrm{C}(\mathrm{O})-\mathrm{Ph}^{27 \mathrm{~g}}$. Presumably, the major part of the negative charge in $2 \mathrm{a}$ is located at the sulphur atom, which has a higher polarizability than oxygen. We therefore describe $2 a$ as a lithium thiolate. However, because the dimer is bridged by $\mathrm{O}(1)$, the highest charge density is located at this atom, the hardest Lewis base of the two.

Structure in Solution. The solution behaviour of the lithium thiolates $2 \mathrm{a}$ and $2 \mathrm{c}$ and the aluminum thiolate $2 \mathrm{e}$ was studied by cryoscopy in benzene, with naphthalene as an internal reference, and by low-temperature NMR. By cryoscopy, no concentration dependence was observed over a concentration range of 0.008 to $0.1 \mathrm{M}$. The observed molecular weights of $440 \pm 50$ for $2 \mathrm{a}$ (calculated value: 460 ), $380 \pm 40$ for $2 c$ (375) and $390 \pm 40$ for $2 e$ (436) seem to correlate well with a monomeric species in solution for both lithium thiolates. For the aluminum compound $2 \mathrm{z}$, a monomeric structure is expected. ${ }^{28}$ However, it is highly unlikely that the lithium compounds are monomeric with 1 equivalent of $\mathrm{Et}_{2} \mathrm{O}$ coordinating.

The observed molecular weights can also be rationalized by higher aggregates $[\mathrm{LiR}]_{\mathbf{n}}$ (e.g. hexamers) and $n$ equivalents of free $\mathrm{Et}_{2} \mathrm{O}$. In fact, this interpretation is in accord with NMR measurements. The $\mathrm{Et}_{2} \mathrm{O}$ signals are almost exactly at the position of free $\mathrm{Et}_{2} \mathrm{O}$ over a temperature range of $190-298 \mathrm{~K}$ in toluene- $d_{8}$, indicating the 
absence of any significant interaction between $\mathrm{Et}_{2} \mathrm{O}$ and the lithium thiolate. Moreover, the coordinated $\mathrm{Et}_{2} \mathrm{O}$ of $2 \mathrm{a}$ can be almost completely removed by repeatedly dissolving the compound in benzene and evaporating in vacuo. The $\mathrm{Et}_{2} \mathrm{O}$ compound that is obtained is very soluble in common organic solvents, even in pentane. The NMR signals of this compound are almost identical to those of $2 \mathbf{a}$, over the temperature range of 190-298 K. We did not succeed in purifying the $\mathrm{Et}_{2} \mathrm{O}$-free compound to such an extent that a cryoscopic determination of the aggregation state of this compound would be meaningful.

Table 2: Relevant ${ }^{1} \mathrm{H}$ and ${ }^{13} \mathrm{C}$ NMR Data for Compounds $2 \mathrm{a}-2 \mathrm{e}$

\begin{tabular}{|c|c|c|c|c|c|}
\hline${ }^{1} \mathrm{H}$ NMR $\left(\mathrm{C}_{6} \mathrm{D}_{6}, \mathrm{ppm}^{\mathrm{b}}\right)$ & $2 \mathbf{a}$ & $\mathbf{2 b}$ & $2 c$ & 2d & $2 e$ \\
\hline $\mathbf{N}-\mathbf{H}$ & 9.05 & 7.36 & 8.51 & 8.31 & 8.78 \\
\hline $\mathrm{O}-\mathrm{CH}_{2} \mathrm{CH}_{3}$ & 4.15 & 4.23 & 4.23 & 3.88 & 3.75 \\
\hline \multirow[t]{2}{*}{$\mathrm{Si}\left(\mathrm{CH}_{3}\right)_{2}$} & 0.21 & 0.21 & - & 0.19 & 0.01 \\
\hline & & 0.05 & & & \\
\hline${ }^{13} \mathrm{C}$ NMR $\left(\mathrm{C}_{6} \mathrm{D}_{6}, \mathrm{ppm}^{\mathrm{b}}\right)$ & $2 a$ & $\mathbf{2 b}$ & $2 c$ & 2d & $2 e$ \\
\hline $\mathrm{C}=\mathrm{S}$ & 178.6 & 181.5 & 182.9 & n.d. ${ }^{a}$ & 174.2 \\
\hline $\mathrm{C}=\mathrm{O}$ & 172.1 & 171.2 & 171.2 & n.d $\mathbf{d}^{\mathrm{a}}$ & 171.3 \\
\hline$S=C-C-C=O$ & 100.1 & 97.5 & 107.3 & n.d. ${ }^{\mathrm{a}}$ & 99.9 \\
\hline $\mathrm{O}-\mathrm{CH}_{2} \mathrm{CH}_{3}$ & 60.1 & 59.8 & 59.7 & 61.9 & 62.3 \\
\hline
\end{tabular}

a: not determined, because of the limited solubility of $2 \mathrm{~d}$ in $\mathrm{C}_{6} \mathrm{D}_{6} ;{ }^{\mathrm{b}}$ : relative to TMS

NMR spectroscopy: The lithium thiolates $2 \mathrm{a}-\mathrm{c}$ display similar ${ }^{1} \mathrm{H}$ and ${ }^{13} \mathrm{C}$ NMR patterns. Hence, we assume that the solution structure of $2 \mathbf{b}$ and $2 \mathrm{c}$ is similar to that of $2 \mathrm{a}$. The multiplicity of the signals in ${ }^{1} \mathrm{H}$ and ${ }^{13} \mathrm{C}$ NMR for the STABASE group of $2 a$ and $2 b$ and the N-ethyl groups of $2 c$ shows, that in all three compounds rotation around the $\mathrm{C}(8)-\mathrm{N}(2)$ bond is fast on the NMR time scale.

The ${ }^{1} \mathrm{H}$ and ${ }^{13} \mathrm{C}$ NMR spectral data (table 2 ) of $2 \mathrm{~d}$ and $2 \mathrm{e}$ differ only slightly from those of $2 \mathrm{a}$. Noteworthy, the ester $\mathrm{CH}_{2}$ protons in both $2 \mathrm{~d}$ and $2 \mathrm{e}$ are shifted $0.4 \mathrm{ppm}$ to higher field, suggesting that in $2 \mathrm{~d}$ and $2 e$ coordination of the alkoxy oxygen atom to the metal plays a role. Precedent exists for the coordination of the alkoxy rather than the carbonyl oxygen atom to the metal in ester complexes of zinc and aluminum 29.

\section{Reactions of Lithium Thiolates $2 a \cdot c$}

Hydrolysis: The lithium thiolates 2a-c were hydrolysed, affording thiomalonamic esters 3a-c. (scheme 3). The products were characterized by ${ }^{1} \mathrm{H}$ and ${ }^{13} \mathrm{C}$ NMR, IR, and GCMS. Hydrolysis of lithium thiolates $2 \mathrm{a}$ and $\mathbf{2 b}$ is a rather slow reaction. Deprotection of the STABASE moiety oocurs readily, necessitating the use of exactly one equivalent of water. In this way the STABASE-protected ${ }^{17}$ thiomalonamic esters $3 \mathrm{a}$ and $3 \mathrm{~b}$ were obtained. When an excess of water was used, $3 \mathrm{a}$ was deprotected to $4 \mathrm{a}$. 

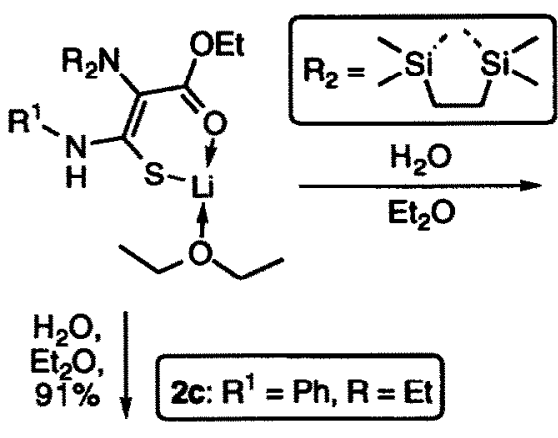

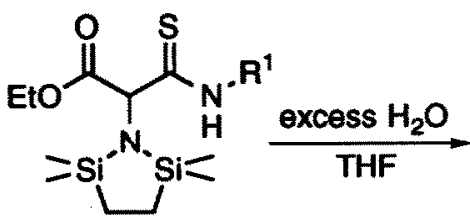

3a: $R^{1}=\mathrm{Ph}(34 \%)$

3b: $R^{1}=\mathrm{PhCH}_{2}(76 \%)$<smiles>[R7]NC(=S)C(N)C(=O)OCC</smiles>

4a: $\mathrm{P}^{1}=\mathrm{Ph}$<smiles></smiles>

$3 c^{\prime}$<smiles>CCOC(=O)C(C(=S)Nc1ccccc1)N(CC)CC</smiles>

scheme 3

Although $2 c$ does not contain sensitive protecting groups, the hydrolysis of this compound with more than one equivalent of water leads to unidentified side-products. Hydrolysis of $2 c$ (scheme 3 ) with one equivalent of water affords both the $C$-protonated product (thiomalonamic ester $3 \mathrm{c}$ ) and the S-protonated tautomer ( $\beta$-enamino ester $3 c^{\prime}$, possessing an enethiol function ${ }^{30}$ ) in a $8: 92$ ratio. The selectivity of the protonation cannot be determined precisely, because the product slowly equilibrates to a $38: 62$ ratio of $3 c$ and $3 c^{\prime}\left(t_{1 / 2}=3 \mathrm{~h}\right.$. at $20^{\circ} \mathrm{C}$ in $\mathrm{C}_{6} \mathrm{D}_{6}$ ). The initially observed 8:92 ratio is considered the minimum value for the regioselectivity of the protonation. The unexpected reaction of lithium thiolate $2 c$ suggests, that the $\beta$-enamino ester $3 c$ ' is stabilized by overlap of the $\mathrm{p}_{\mathrm{z}}$ orbital of the $\mathrm{Et}_{2} \mathrm{~N}$ nitrogen atom with the $\mathrm{C}=\mathrm{C}-\mathrm{C}=\mathrm{O}$ delocalized system. The STABASE protected amino substituent of $\mathbf{3 a}$ and $\mathbf{3 b}$ lacks the possibility for this stabilisation, because the $\mathrm{p}_{\mathrm{z}}$ orbital of the nitrogen atom is delocalized into low-lying orbitals of the two attached silicon atoms. Consequently, hydrolysis of $2 a$ and $2 b$ affords no $S$-protonated product.

By deprotonating an equilibrated mixture of $3 c$ and $3 c^{\prime}$ with LiHMDS, the starting lithium thiolate $2 c$ was obtained quantitatively, proving that $3 c$ and $3 c^{\prime}$ are tautomers. The assignment of $3 c$ and $3 c$ ' is further substantiated by IR, ${ }^{1} \mathrm{H}$ and ${ }^{13} \mathrm{C}$ NMR spectral data. The IR spectrum of the mixture, dissolved in benzene, showed absorptions at 1743 (isolated ester $\mathrm{C}=\mathrm{O}$ ) as well as 1632 and $1592 \mathrm{~cm}^{-1}\left(\mathrm{~N}-\mathrm{C}=\mathrm{C}-\mathrm{C}=\mathrm{O}^{31}\right)$. The major isomer 3c' crystallized readily from pentane/ $\mathrm{Et}_{2} \mathrm{O}(2: 1)$ as colorless needles. This compound shows only the IRabsorptions expected for the $\beta$-enamino ester ${ }^{31}\left(\mathrm{KBr}, 1613\right.$ and $\left.1596 \mathrm{~cm}^{-1}\right)$. Compounds $3 \mathrm{c}$ and $3 \mathrm{a}$ display similar NMR spectra but, $3 c^{\prime}$ is different. The proposed conjugation of the $E_{2} N_{1} p_{z}$ orbital with the enaminone $\pi$ system is supported by the presence of two discrete, broad signals for the $\mathrm{CH}_{2}$ protons of the $\mathrm{N}$-ethyl groups in the ${ }^{1} \mathrm{H}$ NMR spectrum, showing that the pyramidal inversion is slow on the NMR time scale up to $335 \mathrm{~K}$ in 
toluene- $d_{8}$. The tautomers are not exchanging on the NMR time scale at this temperature, since discrete sets of signals for the two species are observed. Noteworthy, the SH and NH protons do not exchange either at $335 \mathrm{~K}$ in toluene- $d_{8}$.<smiles>[R12]NC1=C(N)C(OCC)=C(C(F)(F)F)[Te](OCC)S1</smiles>

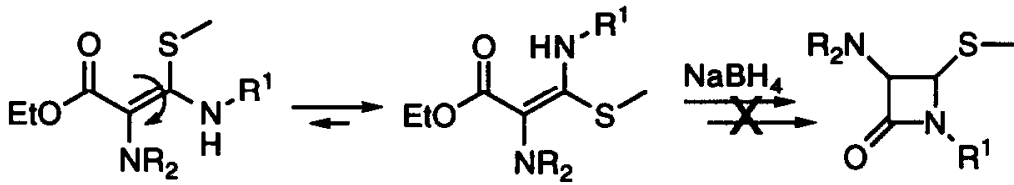

$5 \mathbf{a}^{\prime}, 5 \mathbf{b}^{\prime}, 5 \mathbf{c}^{\prime}$

$5 a, 5 b, 5 c$

5a, 5a': $\mathbf{R}^{1}=\mathrm{Ph}, \mathrm{R}_{2}=-\mathrm{Me}_{2} \mathrm{SiCH}_{2} \mathrm{CH}_{2} \mathrm{SiMe}_{2}-$

5b, 5b': $\mathbf{R}^{1}=\mathrm{PhCH}_{2}, \mathrm{R}_{2}=-\mathrm{Me}_{2} \mathrm{SiCH}_{2} \mathrm{CH}_{2} \mathrm{SiMe}_{2}-$

$5 c, 5 c^{\prime}: R^{1}=P h, R=E t$

scheme 4

Reactions with electrophiles. The lithium thiolates 2 possess several nucleophilic sites. Both the sulphur and the carbon atom $\mathbf{C}(8)$ are soft Lewis bases, whereas the carboxyl oxygen atom is a hard Lewis base. Weak electrophiles will react at the sulphur atom for steric reasons. Thus, compounds 2 2a-c were converted into highly functionalized $\beta$-enamino esters by reacting them with weak carbon electrophiles. The reaction of $2 a$ with iodomethane in refluxing THF afforded the sulphur alkylated product 5a in almost quantitative yield (scheme 4). Initially, a tautomeric compound 5a' is formed, observed as the major product after refluxing for 10 minutes. This kinetic product probably has the $(E)$-configuration, resulting from the configuration of the starting lithium thiolate. By refluxing the reaction mixture for 4 hours, it is completely converted into the thermodynamically more stable product $5 \mathrm{a}$, which probably is the $(Z)$-isomer, having a stabilizing hydrogen bridge $\mathrm{e}^{31}$.<smiles>CC#CCCCCOC(=O)/C(=C(\NCc1ccccc1)SC)N1[SiH](C)CC[Si]1(C)C</smiles>

5b<smiles>CCOC(=O)C(CSC)N(Cc1ccccc1)C1CCCC1</smiles>

5b" (not observed)<smiles>C=C=C=C</smiles>

$5 b^{\prime}$

scheme 5

The N-benzyl substituted lithium thiolate $\mathbf{2 b}$ is alkylated much more easily. Probably the absence of a stabilizing conjugation with the phenyl group is the basis for this enhanced reactivity. The reaction of $\mathbf{2 b}$ with 
iodomethane is complete within minutes at room temperature, affording a $92: 8$ mixture of the $(Z)$ - and $(E)$-isomers $\left({ }^{1} \mathrm{H}\right.$ NMR, $\mathrm{C}_{6} \mathrm{D}_{6}, 20^{\circ} \mathrm{C}$ ) of $5 \mathrm{~b}$ and $5 \mathrm{~b}$ ' as a yellow oil. Another possible explanation ${ }^{32}$ for the presence of two isomers is an equilibrium between $\mathrm{S}, \mathrm{N}$-acetal $\mathbf{5 b}$ and thioimidomalonic ester $\mathbf{5 b}$ " (scheme 5). However, the presence of an imine functionality may be excluded by the multiplicity of the NH proton (triplet), due to coupling with the adjacent $\mathrm{CH}_{2}$ protons, in the ${ }^{1} \mathrm{H}$ NMR spectrum of both isomers. Probably, $5 \mathbf{b}$ " is a transition state structure in the equilibration of $5 \mathbf{b}$ and $5 \mathbf{b}$ '.

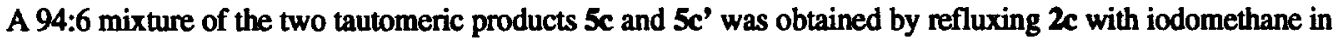
THF (scheme 4). Again, the major product probably is the (Z)-isomer, stabilized by the intramolecular hydrogen bridge. The enaminone system of $5 \mathrm{c}$ is stable to acid hydrolysis; after work-up, $5 \mathrm{c}$ is almost completely recovered $(>95 \%)$. Like $5 \mathbf{a}$ and $\mathbf{5 b}, \mathbf{5 c}$ is an oil, which makes purification difficult. In the presence of lithium iodide, both $5 b$ and $5 \mathrm{c}$ crystallize from $\mathrm{Et}_{2} \mathrm{O}$ as yellow needles. The elemental analysis correlates well with 2 molecules of 5 complexed to 1 molecule of LiI (5b-0.5LiI). In both cases, the presence of lithium in the sample was established by a flame test, and iodide was confirmed by the formation of a precipitate upon addition of alcoholic $\mathrm{AgNO}_{3}$. In the ${ }^{1} \mathrm{H}$ NMR spectra of the crystallized LiI adducts, the original ratios for the (Z)- and $(E)$-isomers of $5 \mathrm{~b}(92: 8)$ and $5 \mathrm{c}$ (94:6) are still present. We therefore believe, that these are the equilibrium ratios. The organic products can be easily obtained quantitatively by dissolving the crystalline compounds in $\mathrm{CH}_{2} \mathrm{Cl}_{2}$, from which $\mathrm{LiI}$ precipitates.

Attempted reduction. To convert the $\beta$-enamino esters into $\beta$-lactams, selective reduction of the $C=C$ double bond and ring closure of the resulting $\beta-\mathrm{S}, \mathrm{N}$-acetal ester was attempted. The 1,4-reduction of simple enaminones and enamino esters has been performed using $\mathrm{NaBH}_{4}$ in alcohols ${ }^{31}$. However, enamino ester $5 \mathrm{c}$ did not react with $\mathrm{NaBH}_{4}$ in 2-propanol at room temperature, whereas refluxing resulted in an unidentified mixture of products, containing (among others) desulphurized compounds ${ }^{33}$, as was evidenced by the disappearance of the S-methyl signals in ${ }^{1} \mathrm{H}$ and ${ }^{13} \mathrm{C}$ NMR.

Attempted ring closure to $\beta$-lactams. Cyclisation of the thiomalonamic esters 3 was attempted with alkylaluminum reagents, according to literature procedures ${ }^{34}$. However, no $\beta$-lactams were formed, due to the stability of the intermediate aluminium thiolates. Instead, the starting materials were recovered in $90 \%$ yield after careful hydrolysis. The same result was obtained when the recrystallized aluminum thiolate $2 e$ was refluxed in toluene.

We have previously reported, that in the reaction of chlorozinc enolates with imines ${ }^{16}$ the intermediate chlorozinc amide is readily cyclized to the corresponding $\beta$-lactam. Lithium thiolate $2 \mathbf{b}$ was transmetallated in situ with $\mathrm{ZnCl}_{2}$ to give the corresponding chlorozinc thiolate. Also in this case no $\beta$-lactam formation was observed after refluxing in toluene for 16 hours. Careful hydrolysis afforded again thiomalonic ester $\mathbf{3 b}$. 


\section{CONCLUDING REMARKS}

The reaction of isothiocyanates with nucleophiles constitutes an easy route to thioamides 35 . Thiomalonamic esters and diesters have been prepared via the reaction of isothiocyanates with sodium acetylacetonates and malonates 32,36 . These compounds have been employed as ligands in organometallic chemistry; e.g. they form very stable, chelated nickel(II) complexes ${ }^{32}$. The C-C coupling rcactions of lithium enolates of protected glycine esters with isothiocyanates afford, in good yields, the corresponding thiomalonamic esters, which are easily purified via crystallisation. However, these thiomalonamic esters 3 have unexpected high stability, to the effect that cyclisation to $\beta$-lactams via standard methodology could not be achieved.

Sulphur alkylation of the lithiated thiomalonamic esters offers a straightforward route to functionalized $\beta$ enamino esters 5. Enaminones and enamino esters are versatile intermediates for the synthesis of heterocyclic products ${ }^{37}$, such as alkaloids and antibiotics. Enaminones similar to compounds $5 \mathrm{a}-\mathrm{c}$, possessing the $\mathrm{S}, \mathrm{N}$-acetal function, have recently been employed in a one-pot synthesis of pyranones ${ }^{38}$, via 1,4 -addition of a Reformatsky reagent. Although $\mathrm{NaBH}_{4}$-reduction of $\beta$-enamino ester $5 \mathrm{c}$ to the corresponding $\beta$-amino ester was unsuccessful, the observed desulphurisation in itself is promising. Selective desulphurisation offers an entry to 4-unsubstituted $\beta$-lactams, via cyclisation of the intermediate $\beta$-amino ester.

\section{EXPERIMENTAL SECTION}

General Data. All synthetic manipulations with air-sensitive reagents were carried out under a dry, inert nitrogen atmosphere using standard Schlenk techniques. Solvents were dried and distilled from sodium $/$ benzophenone prior to use. Diisopropylamine and hexamethyldisilazane were distilled at atmospheric pressure and stored over molsieves ( $3 \AA$ ). Ethyl [(2,2,5,5-tetramethyl-1-aza-2,5-disila)cyclopentyl]acetate (1a) ${ }^{17}$, ethyl(diethylamino)acetate (1b) ${ }^{16 e}$, and dry zinc chloride ${ }^{39}$ were prepared according to literature procedures. ${ }^{1} \mathrm{H}$ and ${ }^{13} \mathrm{C}$ NMR spectra were recorded on a Bruker AC 200 and a Bruker AC 300 spectrometer in chloroform-d or benzene- $d_{6}$. Chemical shifts are in ppm relative to TMS; coupling constants are presented in hertz (Hz). IR spectra were recorded on a Mattson Galaxy FTIR 5000 Spectrometer. Mass spectra (EI, $70 \mathrm{eV}$ ) of pure compounds were recorded on a Unicam 610 Automass GCMS System using a direct inlet probe. Melting points and boiling points are uncorrected. Elemental analyses were performed by the Institute of Applied Chemistry TNO, Zeist, The Netherlands, and Dornis und Kolbe Mikroanalytisches Laboratorium, Mülheim a/d Ruhr, Germany.

Lithium (ethyl 3-(N-phenyl)amino-3-sulfido-2-([2,2,5,5-tetramethyl-1-aza-2,5-disila]cyclopentyl)propenoate-kS,O\} OEt $_{2}$ (2a): To a cooled $\left(-78{ }^{\circ} \mathrm{C}\right)$ solution of $6.12 \mathrm{~g}(60.5 \mathrm{mmol})$ of diisopropylamine in $100 \mathrm{ml}$ of $\mathrm{Et}_{2} \mathrm{O} 60.5 \mathrm{mmol}$ of $n$-butyllithium (40.3 ml of a $1.5 \mathrm{M}$ solution in hexanes) was 
added. After stirring for $15 \mathrm{~min}$ a precooled solution of $14.80 \mathrm{~g}(60.3 \mathrm{mmol})$ of ethyl-[(2,2,5,5-tetramethyl-1-aza2,5-disila)cyclopentyl]acetate in $60 \mathrm{ml}$ of $\mathrm{Et}_{2} \mathrm{O}$ was added over a $5 \mathrm{~min}$ period via a dropping funnel. Stirring was continued for $30 \mathrm{~min}$ at $-78{ }^{\circ} \mathrm{C}$, followed by the addition of $8.15 \mathrm{~g}(60.3 \mathrm{mmol})$ of phenylisothiocyanate. The solution was warmed to $-30^{\circ} \mathrm{C}$ in $3 \mathrm{~h}$ and was kept at this temperature overnight, resulting in the formation of an off-white precipitate, that redissolved upon warming to room temperature to give a clear, yellow solution. All volatiles were completely removed in vacuo. Recrystallisation from a $1: 3 \mathrm{Et}_{2} \mathrm{O}$ /pentane solution afforded $22.16 \mathrm{~g}$. (48.2 mmol, 80\%) of yellow disk-shaped crystals in 2 crystallisations. ${ }^{1} \mathrm{H}$ NMR $\left(\mathrm{C}_{6} \mathrm{D}_{6}\right): \delta 9.05(\mathrm{~s}, 1 \mathrm{H}, \mathrm{NH}) ; 7.84$ (d, $J=7.6,2 \mathrm{H}, o-\mathrm{Ph}-\mathrm{H}$ ); 7.17 (dd, $J=7.6,8.0,2 \mathrm{H}, m-\mathrm{Ph}-\mathrm{H}$ ); 6.95 (t, $J=8.0,1 \mathrm{H}, \mathrm{p}-\mathrm{Ph}-\mathrm{H}$ ); 4.15 (q, $J=7.1,2 \mathrm{H}$, $\mathrm{OCH}_{2} \mathrm{CH}_{3}$ ); 3.30 (q, $J=7.0 ., 4 \mathrm{H}, \mathrm{CH}_{2}$ of $\mathrm{Et}_{2} \mathrm{O}$ ); 1.16 (t, $J=7.1,3 \mathrm{H}, \mathrm{OCH}_{2} \mathrm{CH}_{3}$ ); 1.08 (t, $J=7.0,6 \mathrm{H}, \mathrm{CH}_{3}$ of $\left.\mathrm{Et}_{2} \mathrm{O}\right) ; 0.91\left(\mathrm{~m}, 4 \mathrm{H}, \mathrm{SiCH} \mathrm{CH}_{2} \mathrm{Si}\right) ; 0.21\left(\mathrm{~s}, 12 \mathrm{H}, \mathrm{Si}\left[\mathrm{CH}_{3}\right]_{2}\right) .{ }^{13} \mathrm{C}$ NMR $\left(\mathrm{C}_{6} \mathrm{D}_{6}\right): \delta 178.6(\mathrm{C}=\mathrm{S}) ; 172.1(\mathrm{C}=\mathrm{O})$; 141.4, 128.5, 124.7, $124.2(\operatorname{aryl~C}) ; 100.1(\mathrm{C}[=\mathrm{S}]-\mathrm{C}-\mathrm{C}[=\mathrm{O}]-) ; 65.8\left(\mathrm{CH}_{2}\right.$ of $\left.\mathrm{Et}_{2} \mathrm{O}\right) ; 60.1\left(\mathrm{OCH}_{2} \mathrm{CH}_{3}\right) ; 15.3\left(\mathrm{CH}_{3}\right.$ of $\left.\mathrm{Et}_{2} \mathrm{O}\right) ; 14.6\left(\mathrm{OCH}_{2} \mathrm{CH}_{3}\right) ; 9.0\left(\mathrm{SiCH}_{2} \mathrm{CH}_{2} \mathrm{Si}\right) ; 1.0,0.1\left(\mathrm{Si}\left[\mathrm{CH}_{3}\right]_{2}\right)$. Anal. Calcd for $\mathrm{C}_{21} \mathrm{H}_{37} \mathrm{LiN}_{2} \mathrm{O}_{3} \mathrm{SSi}_{2}$ : C $54.75 ; \mathrm{H} 8.09 ; \mathrm{N}$ 6.08. Found: C 54.38; H 7.83; N 6.04.

Lithium \{ethyl 3-(N-benzyl)amino-3-sulfido-2-([2,2,5,5-tetramethyl-1-aza-2,5-disila]cyclopentyl)propenoate-kS,O\} $\operatorname{OEt}_{2}(2 \mathrm{~b})$ : Via the same procedure, starting from $1.05 \mathrm{~g}$ (7.2 mmol) benzylisothiocyanate, $2 \mathrm{~b}$ was obtained as a colorless crystalline compound. Yield (1 crystallisation from $\mathrm{Et}_{2} \mathrm{O} /$ pentane): $1.80 \mathrm{~g}(3.7 \mathrm{mmol}, 51 \%) .{ }^{1} \mathrm{H}$ NMR $\left(\mathrm{C}_{6} \mathrm{D}_{6}\right): \delta 7.3(\mathrm{~m}, 3 \mathrm{H}, \mathrm{NH} \& o-\mathrm{Ph}-\mathrm{H}) ; 7.1$ (m, 3H, Ph-H); $5.02\left(\mathrm{~d}, J=5.1,2 \mathrm{H}, \mathrm{NCH}_{2} \mathrm{Ph}\right) ; 4.23\left(\mathrm{q}, J=7.0,2 \mathrm{H}, \mathrm{OCH}_{2} \mathrm{CH}_{3}\right) ; 3.36\left(\mathrm{q}, J=7.0,4 \mathrm{H}, \mathrm{CH}_{2}\right.$ of $\left.\mathrm{Et}_{2} \mathrm{O}\right) ; 1.25(\mathrm{t}, J=$ 7.0, 3H, $\left.\mathrm{OCH}_{2} \mathrm{CH}_{3}\right) ; 1.13\left(\mathrm{t}, J=7.0,6 \mathrm{H}, \mathrm{CH}_{3}\right.$ of Et $\mathrm{Et}_{2} \mathrm{O}$ ); 0.73-0.91 (m, 4H, $\left.\mathrm{SiCH}_{2} \mathrm{CH}_{2} \mathrm{Si}\right) ; 0.21,0.05(\mathrm{~s}, 12 \mathrm{H}$, $\left.\mathrm{Si}_{\left[\mathrm{CH}_{3}\right]}{ }_{2}\right) .{ }^{13} \mathrm{C} \mathrm{NMR}\left(\mathrm{C}_{6} \mathrm{D}_{6}\right): \delta 181.5(\mathrm{C}=\mathrm{S}) ; 171.2(\mathrm{C}=0) ; 139.6,129.1,128.6,127.5(\operatorname{aryl~C}) ; 97.5(\mathrm{C}[=\mathrm{S}]-C$ $\mathrm{C}[=\mathrm{O}]-) ; 65.8\left(\mathrm{CH}_{2}\right.$ of $\left.\mathrm{Et}_{2} \mathrm{O}\right) ; 59.8\left(\mathrm{OCH}_{2} \mathrm{CH}_{3}\right) ; 48.7\left(\mathrm{NCH}_{2} \mathrm{Ph}\right) ; 15.3\left(\mathrm{CH}_{3}\right.$ of $\left.\mathrm{Et}_{2} \mathrm{O}\right) ; 14.6\left(\mathrm{OCH}_{2} \mathrm{CH}_{3}\right) ; 9.0$ $\left.\left(\mathrm{SiCH}_{2} \mathrm{CH}_{2} \mathrm{Si}\right) ; 0.9,0.1\left(\mathrm{Si}_{[} \mathrm{CH}_{3}\right]_{2}\right)$. Anal. Calcd for $\mathrm{C}_{22} \mathrm{H}_{39} \mathrm{LiN}_{2} \mathrm{O}_{3} \mathrm{SSi}_{2}$ : C 55.66; $\mathrm{H} 8.28 ; \mathrm{N} \mathrm{5.90;} \mathrm{S}$ 6.75. Found C 55.53; H 8.35; N 5.94; $\mathrm{S} 6.84$.

Lithium \{ethyl 2-(N,N-diethyl)amino-3-(N-phenyl)amino-3-sulfidopropenoate-kS,O\} $-\mathbf{E t}_{2} \mathrm{O}$ (2c): A solution of $4.62 \mathrm{~g}$ (28.7 mmol) of HMDS in $100 \mathrm{ml}$ of THF was cooled to $0{ }^{\circ} \mathrm{C}$. After addition of 28.7 $\mathrm{mmol}$ of BuLi (18.0 ml of a $1.6 \mathrm{M}$ solution in hexane), $4.57 \mathrm{~g}$ of ester $1 \mathrm{~b}$ and $3.88 \mathrm{~g}$ of phenylisothiocyanate (both $28.7 \mathrm{mmol}$ ) with $10 \mathrm{~min}$ intervals, the reaction mixture was refluxed for $45 \mathrm{~min}$. After cooling to room temperature, all volatiles were removed in vacuo, leaving a yellow solid. Yellow disk-shaped crystals of $2 \mathrm{c}$ were obtained by crystallisation from $\mathrm{Et}_{2} \mathrm{O}$. Yield: $8.16 \mathrm{~g}(21.8 \mathrm{mmol}, 76 \%)$. ${ }^{1} \mathrm{H}$ NMR $\left(\mathrm{C}_{6} \mathrm{D}_{6}\right): \delta 8.51(\mathrm{~s}, 1 \mathrm{H}, \mathrm{NH})$; 7.89 (d, $J=7.6,2 \mathrm{H}, o-\mathrm{Ph}-\mathrm{H}) ; 7.16$ (dd, $J=7.6,7.4,2 \mathrm{H}, m-\mathrm{Ph}-\mathrm{H}) ; 6.91$ (t $J=7.4,1 \mathrm{H}, p-\mathrm{Ph}-\mathrm{H}$ ); 4.23 (q, $J=7.1$, $2 \mathrm{H}, \mathrm{OCH}_{2} \mathrm{CH}_{3}$ ); 3.32 (q, $J=7.0,4 \mathrm{H}, \mathrm{CH}_{2}$ of $\left.\mathrm{Et}_{2} \mathrm{O}\right) ; 2.95\left(\mathrm{~m}, 4 \mathrm{H}, \mathrm{N}\left[\mathrm{CH}_{2} \mathrm{CH}_{3}\right]_{2}\right) ; 1.17(\mathrm{t}, J=7.1,3 \mathrm{H}$, $\left.\mathrm{OCH}_{2} \mathrm{CH}_{3}\right) ; 1.08,1.05\left(\mathrm{~h} J=7.0,12 \mathrm{H}, \mathrm{CH}_{3}\right.$ of $\mathrm{Et}_{2} \mathrm{O}$ and $\left.\mathrm{N}\left[\mathrm{CH}_{2} \mathrm{CH}_{3}\right]_{2}\right) \cdot{ }^{13} \mathrm{C}-\mathrm{NMR}\left(\mathrm{C}_{6} \mathrm{D}_{6}\right): \delta 182.9(\mathrm{C}=\mathrm{S})$; 171.2 (C=0); 141.7, 128.4, 124.0, 123.7 (Ph-C); $107.3\left(\mathrm{Et}_{2} \mathrm{~N}-\mathrm{C}\right) ; 65.7\left(\mathrm{CH}_{2}\right.$ of $\left.\mathrm{Et}_{2} \mathrm{O}\right) ; 59.7\left(\mathrm{OCH}_{2} \mathrm{CH}_{3}\right) ; 48.8$ 
(N[CH $\left.\left.\mathrm{CH}_{3}\right]_{2}\right) ; 15.1\left(\mathrm{CH}_{3}\right.$ of Et $\left.\left.2 \mathrm{O}\right) ; 14.8\left(\mathrm{OCH}_{2} \mathrm{CH}_{3}\right) ; 14.5\left(\mathrm{~N}_{2} \mathrm{CH}_{2} \mathrm{CH}_{3}\right]_{2}\right)$. Anal. Caled for $\mathrm{C}_{19} \mathrm{H}_{31} \mathrm{LiN}_{2} \mathrm{O}_{3} \mathrm{~S}$ (MW = 374.47): C 60.94; H 8.34; N 7.48. Found: C 61.06; H 8.39; N 7.42.

X-Ray data Collection, Structure Determination, and Refinement of Lithium thiolate 2a: A yellowish, plate-shaped crystal was glued to the tip of a glass fiber and transferred into the cold nitrogen stream on an Enraf-Nonius CAD4-F diffractometer. Accurate unit-cell parameters and an orientation matrix were determined by least squares refinement of 25 well-centered reflections (SET4) in the range $10.6^{\circ}<\theta<19.5^{\circ}$. Reduced-cell calculations did not indicate higher lattice symmetry. ${ }^{40}$ Crystal data are presented in table 3 . Intensity data of 7604 reflections were collected in the range $1.16^{\circ}<\Theta<27.5^{\circ}, 5867$ of which are independent. 3746 reflections with intensities above the $2.5 \sigma(I)$ level were used in the structure analysis. Data were corrected for $L p$ effects and for observed linear decay, but not for absorption. The structure was solved by automated direct methods (SHELXS86 ${ }^{41}$ ). Refinement on $F$ was carried out by full-matrix least-squares techniques (SHELX76 ${ }^{42}$ ). Hydrogen atoms were included in the refinement on calculated positions $(\mathrm{C}-\mathrm{H}=0.98 \AA$ ) riding on their carrier atoms, except for the amine hydrogen atom, which was located on a difference Fourier map and subsequently included in the refinement. All non-hydrogen atoms were refined with anisotropic thermal parameters; the hydrogen atoms were refined with two overall isotropic thermal parameters. A final difference Fourier map showed no residual density outside -0.42 and $0.69 \mathrm{e} \AA^{-3}$. Neutral atom scattering factors were taken from Cromer and $\mathrm{Mann}^{43}$, anomalous dispersions from Cromer and Liberman. 44 Geometrical calculations and illustrations were performed with PLATON. ${ }^{45}$ All calculations were performed on a MicroVAX-II.

Table 3. Crystallographic Data for 2a

\begin{tabular}{llll}
\hline formula & {$\left[\mathrm{C}_{17} \mathrm{H}_{27} \mathrm{LiN}_{2} \mathrm{O}_{2} \mathrm{SSi}_{2} \cdot \mathrm{C}_{4} \mathrm{H}_{10} \mathrm{O}\right]_{2}$} & $D_{\text {calc }} \mathrm{g} \mathrm{cm}^{-3}$ & 1.194 \\
space group & $\mathrm{P} 2_{1} / \mathrm{c}$ & $\mu_{\text {calc }}, \mathrm{cm}^{-1}$ & 2.3 \\
cryst. system & monoclinic & radiation $(\mathrm{Mo} \mathrm{K \alpha}), \AA$ & 0.71073 (Zr-filtered) \\
$Z$ & 2 & $\mathrm{~T}, \mathrm{~K}$ & 100 \\
$\mathrm{Z}, \AA$ & $\mathrm{R}_{\mathrm{F}}^{\mathrm{a}}$ & 0.048 \\
$\mathrm{~b}, \AA$ & $\mathrm{R}_{\mathrm{wF}}$ & 0.071 \\
c, $\AA$ & $14.238(2)$ & & \\
$\beta$, deg. & $10.217(1)$ & & \\
$\mathrm{V}, \AA^{3}$ & $17.810(2)$ & & \\
\hline
\end{tabular}

${ }^{\mathrm{a}} \mathrm{R}_{\mathrm{F}}=\Sigma|| F_{\mathrm{o}}|-| F_{\mathrm{c}}|| / \Sigma\left|F_{\mathrm{o}}\right| ;{ }^{\mathrm{b}} \mathrm{R}_{\mathrm{wF}}=\left[\Sigma\left[\mathrm{w}\left(|| F_{\mathrm{o}}|-| F_{\mathrm{c}}||\right)^{2}\right] / \Sigma\left[\mathrm{w}\left(F_{\mathrm{o}}^{2}\right)\right]\right]^{1 / 2}$

Transmetallations of $2 \mathrm{a}$ :

Chlorozinc \{ethyl 3-(N-phenyl)amino-3-sulfido-2-([2,2,5,5-tetramethyl-1-aza-2,5-disila]cyclopentyl)propenoate-kS,O\} (2d): At room temperature $3.88 \mathrm{~g}(8.4 \mathrm{mmol}$ ) of $2 \mathrm{a}$ was dissolved in $30 \mathrm{ml}$. $\mathrm{Et}_{2} \mathrm{O}$. Addition of $8.5 \mathrm{mmol}$ of zinc chloride $(7.0 \mathrm{ml}$ of a $1.22 \mathrm{M}$ solution in ether) caused the formation of a white 
precipitate. After stirring for $90 \mathrm{~min}$ the lithium chloride was filtered off. An orange foam was obtained by concentrating the filtrate in vacuo. Stirring with hexane yielded $2 \mathrm{~d}$ as a yellow powder. Yield: $3.78 \mathrm{~g}(7.6 \mathrm{mmol}$, 90\%). ${ }^{1} \mathrm{H}$ NMR: $\left(\mathrm{C}_{6} \mathrm{D}_{6}\right): \delta 8.31$ (s, 1H, NH); 7.41 (d, $\left.J=7.7,2 \mathrm{H}, o-\mathrm{Ph}-\mathrm{H}\right) ; 7.08$ (dd, $J=7.7,7.3,2 \mathrm{H}, m-\mathrm{Ph}-\mathrm{H}$ ); 6.96 (t. $J=7.3,1 \mathrm{H}, p-\mathrm{Ph}-\mathrm{H}) ; 3.88$ (br.q. $\left.J=6.9,2 \mathrm{H}, \mathrm{OCH}_{2} \mathrm{CH}_{3}\right) ; 0.98\left(\mathrm{t}, J=7.1,3 \mathrm{H}, \mathrm{OCH}_{2} \mathrm{CH}_{3}\right) ; 0.79(\mathrm{~m}, 4 \mathrm{H}$, $\left.\mathrm{SiCH} \mathrm{CH}_{2} \mathrm{Si}\right) ; 0.19$ (s, $\left.12 \mathrm{H}, \mathrm{Si}\left[\mathrm{CH}_{3}\right]_{2}\right) .{ }^{13} \mathrm{C} \mathrm{NMR}\left(\mathrm{C}_{6} \mathrm{D}_{6}\right): \delta 61.9\left(\mathrm{OCH}_{2} \mathrm{CH}_{3}\right) ; 14.3\left(\mathrm{OCH}_{2} \mathrm{CH}_{3}\right) ; 8.8$ $\left(\mathrm{SiCH} \mathrm{CH}_{2} \mathrm{Si}\right) ; 1.2,-0.3\left(\mathrm{Si}\left[\mathrm{CH}_{3}\right]_{2}\right)$.

Dimethylaluminium \{ethyl 3-(N-phenyl)amino-3-sulfido-2-([2,2,5,5-tetramethyl-1-aza-2,5disila]cyclopentyl)propenoate- $\mathrm{kS}, \mathrm{O}$ ) (2e): At $-50^{\circ} \mathrm{C} 1.30 \mathrm{~g}(2.8 \mathrm{mmol})$ of $2 \mathrm{a}$ was dissolved in $20 \mathrm{ml} \mathrm{of} \mathrm{Et}_{2} \mathrm{O}$. To this solution was added $2.8 \mathrm{mmol}$ of dimethylaluminum chloride $\left(2.8 \mathrm{ml}\right.$ of a $1.0 \mathrm{M}$ solution in $\left.\mathrm{E}_{2} \mathrm{O}\right)$. After slowly warming the yellow reaction mixture to ambient temperature, the solvent was removed in vacuo, affording a microcrystalline solid. The product was stimed in hexane and again dried in vacuo, yielding a yellow powder. Yield: $1.27 \mathrm{~g}$ ( $2.7 \mathrm{mmol}, 97 \%)$. Recrystallisation from $\mathrm{E}_{2} \mathrm{O}$ gave yellow disk-shaped crystals. ${ }^{1} \mathrm{H}$ NMR $\left(\mathrm{C}_{6} \mathrm{D}_{6}\right)$ : $\delta 8.78$ (s, 1H, NH); 7.32 (d, 2H, o-Ph-H); 7.10 (dd, 2H, m-Ph-H); 6.96 (t, 1H, p-Ph-H); 3.75 (q, J = 7.1, 2H, $\left.\mathrm{OCH}_{2} \mathrm{CH}_{3}\right) ; 0.92\left(\mathrm{t}, J=7.1,3 \mathrm{H}, \mathrm{OCH}_{2} \mathrm{CH}_{3}\right) ; 0.76\left(\mathrm{~m}, 4 \mathrm{H}, \mathrm{SiCH}_{2} \mathrm{CH}_{2} \mathrm{Si}\right) ; 0.01\left(\mathrm{~s}, 12 \mathrm{H}, \mathrm{Si}_{[}\left[\mathrm{CH}_{3}\right]\right.$ ); $-0.21(\mathrm{~s}, 6 \mathrm{H}$, $\left.\mathrm{Al}\left[\mathrm{CH}_{3}\right]_{2}\right) .{ }^{13} \mathrm{C} \mathrm{NMR}\left(\mathrm{C}_{6} \mathrm{D}_{6}\right): \delta 174.2(\mathrm{C}=\mathrm{S}) ; 171.3(\mathrm{C}=\mathrm{O}) ; 138.7,129.3,126.7,126.0(\mathrm{Ph}-\mathrm{C}) ; 99.9(\mathrm{C}=\mathrm{S}]-\mathrm{C}-$ $\left.\mathrm{C}[=\mathrm{O}]-) ; 62.3\left(\mathrm{OCH}_{2} \mathrm{CH}_{3}\right) ; 14.3\left(\mathrm{OCH}_{2} \mathrm{CH}_{3}\right) ; 8.6\left(\mathrm{SiCH}_{2} \mathrm{CH}_{2} \mathrm{Si}\right) ; 0.6,-0.5\left(\mathrm{Si}_{[} \mathrm{CH}_{3}\right]_{2}\right) ;-8.6\left(\mathrm{br}, \mathrm{Al}_{[}\left[\mathrm{CH}_{3}\right]_{2}\right)$.

General procedure for the hydrolysis of 2: To a solution of $0.5 \mathrm{mmol} \mathrm{of} 2 \mathrm{in} 10 \mathrm{ml}$ of $\mathrm{Et}_{2} \mathrm{O}$ was added $0.55 \mathrm{mmol}$ of $\mathrm{H}_{2} \mathrm{O}\left(0.20 \mathrm{ml}\right.$ of a $2.75 \mathrm{M}$ solution in THF), $0.1 \mathrm{~g}$ of solid $\mathrm{NH}_{4} \mathrm{Cl}$ and $2 \mathrm{~g}$ of $\mathrm{MgSO}_{4}$. After stirring for $30 \mathrm{~min}$, the mixture was filtrated and the residu was washed with $\mathrm{Et}_{2} \mathrm{O}$ (two times $10 \mathrm{ml}$ ). Evaporation of the combined organic layers yielded the hydrolysed product.

Ethyl 3-(N-phenylamino)-2-([2,2,5,5-tetramethyl-1-aza-2,5-disila]cyclopentyl)-3-thioxopropanoate (3a): Off-white solid, that was shown by ${ }^{1} \mathrm{H}$ NMR to consist of the hydrolysis product $3 \mathrm{a}$ and the deprotected product $4 \mathrm{a}$ in a 5:1 ratio. Extraction with pentane and crystallisation from pentane afforded yellow crystals of 3a. Yield: $34 \%$. Mp: $79^{\circ} \mathrm{C}$. ${ }^{1} \mathrm{H}-\mathrm{NMR}\left(\mathrm{C}_{6} \mathrm{D}_{6}\right): \delta 10.21$ (s, $\left.1 \mathrm{H}, \mathrm{NH}\right) ; 8.09$ (d, J=8.0, 2H, o-Ph-H); 7.08 (dd, $J=8.0,7.3,2 \mathrm{H}, m-\mathrm{Ph}-\mathrm{H}$ ); 6.91 (t. $J=7.3,1 \mathrm{H}, p-\mathrm{Ph}-\mathrm{H}$ ); 4.99 (s, 1H, C[=S]-CH-C=O); 4.03 (q, $J=7.1$ $\mathrm{Hz}, 2 \mathrm{H}, \mathrm{OCH}_{2} \mathrm{CH}_{3}$ ); 1.00 (t, $\left.\mathrm{J}=7.1,3 \mathrm{H}, \mathrm{OCH}_{2} \mathrm{CH}_{3}\right) ; 0.70\left(\mathrm{~m}, 4 \mathrm{H}, \mathrm{SiCH}_{2} \mathrm{CH}_{2} \mathrm{Si}\right.$ ); $0.23,0.00$ (s, 12H,

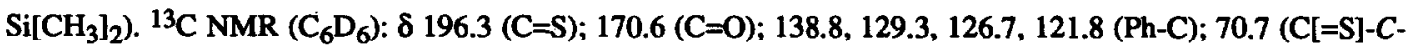
$\left.\mathrm{C}[=\mathrm{O}]) ; 61.8\left(\mathrm{OCH}_{2} \mathrm{CH}_{3}\right) ; 13.9\left(\mathrm{OCH}_{2} \mathrm{CH}_{3}\right) ; 8.7\left(\mathrm{SiCH}_{2} \mathrm{CH}_{2} \mathrm{Si}\right) ; 0.0,-0.3\left(\mathrm{Si}_{\left[\mathrm{CH}_{3}\right.}\right]_{2}\right)$. IR $\left(\mathrm{KBr}, \mathrm{cm}^{-1}\right): 3240$ (NH), $1731(\mathrm{C}=\mathrm{O}), 1528$ (N-C=S). Anal. Caled for $\mathrm{C}_{17} \mathrm{H}_{28} \mathrm{~N}_{2} \mathrm{O}_{2} \mathrm{SSi}_{2}$ : C 53.64; $\mathrm{H} 7.41 ; \mathrm{N}$ 7.36. Found: $\mathrm{C}$ 53.75; H 7.55; N 7.32. 
Ethyl 3-(N-benzylamino)-2-([2,2,5,5-tetramethyl-1-aza-2,5-disila]cyclopentyl)-3-thioxopropanoate (3b): White solid. The product was recrystallized from hexane, affording $3 \mathbf{b}$ as white needles. Yield: $76 \%$. Mp: $87^{\circ} \mathrm{C} .{ }^{1} \mathrm{H}$ NMR (C $\left.{ }_{6} \mathrm{D}_{6}\right): \delta 8.49$ (br s, $\left.1 \mathrm{H}, \mathrm{NH}\right) ; 7.0-7.1$ (m, 5H, Ph-H); 4.99 (s, 1H, C[=S]-CH$\mathrm{C}=0$ ); 4.75 (d, $J=5.2,2 \mathrm{H}, \mathrm{NCH}_{2} \mathrm{Ph}$ ); $4.03\left(\mathrm{ABX}_{3}, 2 \mathrm{H}, \mathrm{OCH}_{2} \mathrm{CH}_{3}\right) ; 1.01$ (t, $\left.J=7.1,3 \mathrm{H}, \mathrm{OCH}_{2} \mathrm{CH}_{3}\right) ; 0.5-0.7$ $\left(\mathrm{m}, 4 \mathrm{H}, \mathrm{SiCH}_{2} \mathrm{CH}_{2} \mathrm{Si}\right) ; 0.14,-0.06\left(\mathrm{~s}, 12 \mathrm{H}, \mathrm{Si}\left[\mathrm{CH}_{3}\right]_{2}\right) .{ }^{13} \mathrm{C} \mathrm{NMR}\left(\mathrm{C}_{6} \mathrm{D}_{6}\right): \delta 198.7(\mathrm{C}[=\mathrm{S}]) ; 170.8(-\mathrm{C}[=\mathrm{O}]) ;$ 136.4, 129.0, 128.8, $128.2(\mathrm{Ph}-\mathrm{C}) ; 69.1$ (C[=S]-C-C[=O ]); $61.7\left(\mathrm{OCH}_{2} \mathrm{CH}_{3}\right) ; 49.5\left(\mathrm{NCH}_{2} \mathrm{Ph}\right) ; 13.9$ $\left(\mathrm{OCH}_{2} \mathrm{CH}_{3}\right) ; 8.5\left(\mathrm{SiCH}_{2} \mathrm{CH}_{2} \mathrm{Si}\right) ; 0.1,-0.2\left(\mathrm{Si}\left[\mathrm{CH}_{3}\right] 2\right) . \mathrm{IR}\left(\mathrm{KBr}, \mathrm{cm}^{-1}\right): 3314(\mathrm{NH}), 1727(\mathrm{C}=\mathrm{O}), 1532(\mathrm{~N}-\mathrm{C}=\mathrm{S})$. Anal. Calcd for $\mathrm{C}_{18} \mathrm{H}_{30} \mathrm{~N}_{2} \mathrm{O}_{2} \mathrm{SSi}_{2}$ : $\mathrm{C} 54.78 ; \mathrm{H} 7.66 ; \mathrm{N}$ 7.10. Found: $\mathrm{C} 54.66 ; \mathrm{H} 7.65 ; \mathrm{N}$ 7.13.

Ethyl 2-(N,N-diethyl)amino-3-(N-phenyl)amino-3-thioxopropanoate (3c) and ethyl 2-(N,Ndiethyl)amino-3-mercapto-3-(N-phenyl)aminopropenoate (3c'): Yellow oil, that solidified upon standing. Yield: $91 \%$. The product was shown to be a mixture of two isomeric compounds. Crystallisation from pentane/ $\mathrm{Et}_{2} \mathrm{O}$ (2:1) yielded the major isomer (enamino ester) as white needles. Yield: $36 \%$. B-enamino ester 3c': Mp: 54 $55^{\circ} \mathrm{C} .{ }^{1} \mathrm{H}$ NMR $\left(\mathrm{C}_{6} \mathrm{D}_{6}\right): \delta 12.57$ (s, 1H, OH); 12.03 (s, $1 \mathrm{H}, \mathrm{NH}$ ); 8.03 (d, $J=7.6,2 \mathrm{H}, o-\mathrm{Ph}-\mathrm{H}$ ); 7.12 (dd, $J=7.6$, 7.4, 2H, $m-\mathrm{Ph}-\mathrm{H}) ; 6.88(\mathrm{t}, J=7.4,1 \mathrm{H}, \mathrm{p}-\mathrm{Ph}-\mathrm{H}) ; 4.09$ (q, $J=7.1,2 \mathrm{H}, \mathrm{OCH}_{2} \mathrm{CH}_{3}$ ); 2.90, 2.54 (br m, 4H, $\left.\mathrm{N}\left[\mathrm{CH}_{2} \mathrm{CH}_{3}\right]_{2}\right) ; 0.99\left(\mathrm{t}, J=7.1,3 \mathrm{H}, \mathrm{OCH}_{2} \mathrm{CH}_{3}\right) ; 0.92\left(\mathrm{t}, J=7.1,6 \mathrm{H}, \mathrm{N}\left[\mathrm{CH}_{2} \mathrm{CH}_{3} \mathrm{l}_{2}\right) .{ }^{13} \mathrm{C} \mathrm{NMR}\left(\mathrm{C}_{6} \mathrm{D}_{6}\right): \delta 181.8\right.$ $(\mathrm{C}=\mathrm{S}) ; 162.9(\mathrm{C}=\mathrm{O}) ; 142.1,128.6,123.9,123.1(\mathrm{Ph}-\mathrm{C}) ; 97.2\left(\mathrm{Et}_{2} \mathrm{~N}-\mathrm{C}\right) ; 58.6\left(\mathrm{OCH}_{2} \mathrm{CH}_{3}\right) ; 50.5\left(\mathrm{~N}\left[\mathrm{CH}_{2} \mathrm{CH}_{3}\right]_{2}\right)$; $\left.14.9\left(\mathrm{OCH}_{2} \mathrm{CH}_{3}\right) ; 10.4\left(\mathrm{~N}_{\mathrm{CH}_{2}} \mathrm{CH}_{3}\right]_{2}\right)$. IR $\left(\mathrm{C}_{6} \mathrm{H}_{6}, \mathrm{~cm}^{-1}\right): 1632,1592(\mathrm{~N}-\mathrm{C}=\mathrm{C}-\mathrm{C}=\mathrm{O}) . \mathrm{IR}\left(\mathrm{KBr}, \mathrm{cm}^{-1}\right): 1613$, $1596(\mathrm{~N}-\mathrm{C}=\mathrm{C}-\mathrm{C}=\mathrm{O})$. MS: $\mathrm{m} / \mathrm{z}=294$. Anal. Calcd for $\mathrm{C}_{15} \mathrm{H}_{22} \mathrm{~N}_{2} \mathrm{O}_{2} \mathrm{~S}: \mathrm{C} 61.19 ; \mathrm{H}$ 7.53; $\mathrm{N}$ 9.52. Found: C 61.25; H 7.44; N 9.54. Thiomalonamic ester $3 \mathrm{c}:{ }^{1} \mathrm{H}$ NMR $\left(\mathrm{C}_{6} \mathrm{D}_{6}\right): \delta 10.91(\mathrm{~s}, 1 \mathrm{H}, \mathrm{NH}) ; 7.97(\mathrm{~d}, J=7.6,2 \mathrm{H}, o-\mathrm{Ph}-\mathrm{H})$; 7.09 (dd, $J=7.6,7.4,2 \mathrm{H}, m-\mathrm{Ph}-\mathrm{H}$ ); 6.93 (t, $J=7.4,1 \mathrm{H}, p-\mathrm{Ph}-\mathrm{H}) ; 4.52$ (s, 1H, N-CH-COO); 4.05 (q, $J=7.1,2 \mathrm{H}$, $\left.\left.\mathrm{OCH}_{2} \mathrm{CH}_{3}\right) ; 2.57\left(\mathrm{~m}, 4 \mathrm{H}, \mathrm{N}\left[\mathrm{CH}_{2} \mathrm{CH}_{3}\right]_{2}\right) ; 1.01\left(\mathrm{t}, J=7.1,3 \mathrm{H}, \mathrm{OCH}_{2} \mathrm{CH}_{3}\right) ; 0.79\left(\mathrm{t} J=7.1,6 \mathrm{H}, \mathrm{N}_{\left[C_{2}\right.} \mathrm{CH}_{3}\right]_{2}\right)$. ${ }^{13} \mathrm{C}-\mathrm{NMR}\left(\mathrm{C}_{6} \mathrm{D}_{6}\right): \delta 193.71(\mathrm{C}=\mathrm{S}) ; 168.28(\mathrm{C}=\mathrm{O}) ; 139.10,129.08,126.33,121.92(\mathrm{Ph}-\mathrm{C}) ; 78.74\left(\mathrm{Et}_{2} \mathrm{~N}-\mathrm{C}\right)$; $\left.61.21\left(\mathrm{OCH}_{2} \mathrm{CH}_{3}\right) ; 44.55\left(\mathrm{~N}\left[\mathrm{CH}_{2} \mathrm{CH}_{3}\right]_{2}\right) ; 14.23\left(\mathrm{OCH}_{2} \mathrm{CH}_{3}\right) ; 12.45\left(\mathrm{~N}_{2} \mathrm{CH}_{2} \mathrm{CH}_{3}\right]_{2}\right)$. IR $\left(\mathrm{C}_{6} \mathrm{H}_{6}, \mathrm{~cm}^{-1}\right): 1743$ $(\mathrm{C}=\mathrm{O})$.

Ethyl 2-amino-3-(N-phenyl)amino-3-thioxopropanoate (4a): A solution of $0.82 \mathrm{~g}$ (1.75 mmol) of $2 \mathrm{a}$ in $20 \mathrm{ml}$ of THF was stirred overnight with $10 \mathrm{ml}$ of $\mathrm{H}_{2} \mathrm{O}$. After addition of $30 \mathrm{ml}$ of $\mathrm{Et}_{2} \mathrm{O}$, the organic layer was separated, dried on magnesium sulfate and filtrated. A beige solid was obtained by in vacuo removal of the solvent. Washing with hexane and recrystallisation of the residue from $\mathrm{E}_{2} \mathrm{O}$ afforded $4 \mathrm{a}$ as a yellow crystalline product. Yield: $0.36 \mathrm{~g}\left(1.5 \mathrm{mmol}, 86 \%\right.$ ) Mp: $76{ }^{\circ} \mathrm{C} .{ }^{1} \mathrm{H} \mathrm{NMR}\left(\mathrm{C}_{6} \mathrm{D}_{6}\right): \delta 11.1(\mathrm{br}, 1 \mathrm{H}, \mathrm{Ph}-\mathrm{NH}) ; 7.92$ (d, $J=7.6,2 \mathrm{H}, o-\mathrm{Ph}-$ H); 7.05 (dd, $J=7.6,7.3,2 \mathrm{H}, m-\mathrm{Ph}-\mathrm{H}) ; 6.90$ (t, $J=7.3,1 \mathrm{H}, p-\mathrm{Ph}-\mathrm{H}) ; 4.10$ (s, 1H, N-CH-COOEt); 4.03 (ABX. $\left.2 \mathrm{H}, \mathrm{OCH}_{a} \mathrm{H}_{b} \mathrm{CH}_{3}\right) ; 1.28\left(\mathrm{br}, 2 \mathrm{H}, \mathrm{NH}_{2}\right) ; 1.02$ (t, $\left.J=7.1,3 \mathrm{H}, \mathrm{OCH}_{2} \mathrm{CH}_{3}\right) .{ }^{13} \mathrm{C}$ NMR $\left(\mathrm{C}_{6} \mathrm{D}_{6}\right): \delta 194.2(\mathrm{C}=\mathrm{S})$; 171.1 (COOEt); 138.4, 128.9, 126.4, 122.1 (aryl C); 66.4 (N-CH-COOEt); $61.8\left(\mathrm{OCH}_{2} \mathrm{CH}_{3}\right) ; 14.0$ $\left(\mathrm{OCH}_{2} \mathrm{CH}_{3}\right)$. IR $\left(\mathrm{KBr}, \mathrm{cm}^{-1}\right): 3339,3254\left(\mathrm{NH}_{2}\right) ; 1745(\mathrm{C}=\mathrm{O}) ; 1496(\mathrm{~N}-\mathrm{C}=\mathrm{S})$. MS: $\mathrm{m} / \mathrm{z}=238$ Anal. Calcd for 
$\mathrm{C}_{11} \mathrm{H}_{14} \mathrm{~N}_{2} \mathrm{O}_{2} \mathrm{~S}:$ C 55.44; H 5.92; N 11.76. Found: C 55.34; H 5.89; $\mathrm{N} 11.64$.

Ethyl 3-methylthio-3-(N-phenyl)amino-2-([2,2,5,5-tetramethyl-1-aza-2,5-disila]cyclopentyl)propenoate (5a): To a solution of $0.83 \mathrm{~g}(1.8 \mathrm{mmol})$ of $2 \mathrm{a}$ in $10 \mathrm{ml}$ THF $0.29 \mathrm{~g}$ ( $2.0 \mathrm{mmol})$ of iodomethane was added. The clear yellow reaction mixture was refluxed for $4 \mathrm{~h}$. In vacuo evaporation of the solvent resulted in a yellow foam. This was dissolved in pentane and the solid material was filtered off. From the pentane solution the S-methylated product was obtained by evaporating to dryness. Yield: $0.72 \mathrm{~g}(1.8 \mathrm{mmol}, 99 \%) .{ }^{1} \mathrm{H}$ NMR $\left(\mathrm{C}_{6} \mathrm{D}_{6}\right)$ : $\delta 9.57$ (s, 1H, NH); 7.46 (d, $J=7.8,2 \mathrm{H}, o-\mathrm{Ph}-\mathrm{H}) ; 7.08$ (dd, $J=7.8,7.3,2 \mathrm{H}, m-\mathrm{Ph}-\mathrm{H}$ ); 6.79 (t, $J=7.3,1 \mathrm{H}, p-\mathrm{Ph}$ $\mathrm{H}$ ); 4.28 (q, $\left.J=7.1,2 \mathrm{H}, \mathrm{OCH}_{2} \mathrm{CH}_{3}\right) ; 1.63\left(\mathrm{~s}, 3 \mathrm{H}, \mathrm{SCH}_{3}\right) ; 1.07\left(\mathrm{t}, J=7.2,3 \mathrm{H}, \mathrm{OCH}_{2} \mathrm{CH}_{3}\right) ; 0.97$ (s, 4H, $\left.\mathrm{SiCH}_{2} \mathrm{CH}_{2} \mathrm{Si}\right) ; 0.25$ (s, 12H, Si[CH$\left.]_{2}\right]_{2}{ }^{13} \mathrm{C} \mathrm{NMR}\left(\mathrm{C}_{6} \mathrm{D}_{6}\right): \delta 169.7(\mathrm{C}=\mathrm{O}) ; 157.7(\mathrm{C}=\mathrm{C}$-SMe); 1429, 129.2, 122.6, $120.9(\operatorname{aryl~C}) ; 112.2\left(\mathrm{C}=C\right.$-COOEt); $62.8\left(\mathrm{OCH}_{2} \mathrm{CH}_{3}\right) ; 15.1\left(\mathrm{SCH}_{3}\right) ; 14.1\left(\mathrm{OCH}_{2} \mathrm{CH}_{3}\right) ; 8.8$ $\left(\mathrm{SiCH} \mathrm{CH}_{2} \mathrm{Si}\right) ; 0.8\left(\mathrm{Si}_{[}\left[\mathrm{CH}_{3}\right]_{2}\right)$.

Ethyl 3-methylthio-3-(N-benzyl)amino-2-([2,2,5,5-tetramethyl-1-aza-2,5-disila]cyclopentyl)propenoate (5b): To a solution of $0.30 \mathrm{~g}(0.75 \mathrm{mmol})$ of $2 \mathrm{~b}$ in $10 \mathrm{ml}$ of THF, $0.12 \mathrm{~g}(0.8 \mathrm{mmol})$ of iodomethane was added. The clear yellow reaction mixture was stirred for $15 \mathrm{~min}$. After concentration, the sticky yellow residue was triturated with benzene. The precipitate was removed by centrifugation, and the solution was concentrated to afford $5 \mathrm{~b}$ as an orange-yellow foam. By ${ }^{1} \mathrm{H}$ NMR it was shown that the product consisted of two isomers in a 92:8 ratio. Recrystallisation from $\mathrm{Et}_{2} \mathrm{O}$ /pentane (1:1) afforded $5 \mathrm{~b} \bullet \mathbf{0 . 5} \mathrm{LiI}$ as off-white block-shaped crystals. Yield: $0.22 \mathrm{~g}(0.46 \mathrm{mmol}, 62 \%)$. Major isomer $5 \mathrm{~h}:{ }^{1} \mathrm{H}$ NMR $\left(\mathrm{C}_{6} \mathrm{D}_{6}\right): \delta 8.75(\mathrm{t}, J=6.8,1 \mathrm{H}, \mathrm{NH}) ; 7.40(\mathrm{~d}, J=$ 7.4, 2H, o-Ph-H); 7.19 (dd, $J=7.4,7.1,2 \mathrm{H}, m-\mathrm{Ph}-\mathrm{H}$ ); 7.04 (t, $J=7.1,1 \mathrm{H}, p-\mathrm{Ph}-\mathrm{H}$ ); 4.40 (d, $J=6.8,2 \mathrm{H}$, $\left.\mathrm{PhCH}_{2} \mathrm{~N}\right) ; 4.24\left(\mathrm{q}, J=7.1,2 \mathrm{H}, \mathrm{OCH}_{2} \mathrm{CH}_{3}\right) ; 1.93\left(\mathrm{~s}, 3 \mathrm{H}, \mathrm{SCH}_{3}\right) ; 1.09$ (t, $\left.J=7.2,3 \mathrm{H}, \mathrm{OCH}_{2} \mathrm{CH}_{3}\right) ; 0.94(\mathrm{~m}, 4 \mathrm{H}$, $\left.\mathrm{SiCH}_{2} \mathrm{CH}_{2} \mathrm{Si}\right) ; 0.04-0.20\left(\mathrm{br}, 12 \mathrm{H}, \mathrm{Si}\left[\mathrm{CH}_{3}\right]_{2}\right) .{ }^{13} \mathrm{C} \mathrm{NMR}\left(\mathrm{C}_{6} \mathrm{D}_{6}\right): \delta 170.2(\mathrm{C}=0) ; 162.9(\mathrm{C}=C-\mathrm{SMe}) ; 139.9$, 128.6, 128.4, 127.2 (aryl C); $109.3\left(\mathrm{C}=C\right.$-COOEt); $61.3\left(\mathrm{OCH}_{2} \mathrm{CH}_{3}\right) ; 51.3\left(\mathrm{PhCH}_{2} \mathrm{~N}\right) ; 16.5\left(\mathrm{SCH}_{3}\right) ; 14.2$ $\left(\mathrm{OCH}_{2} \mathrm{CH}_{3}\right) ; 8.7\left(\mathrm{SiCH}_{2} \mathrm{CH}_{2} \mathrm{Si}\right) ; 0.3\left(\mathrm{br}, \mathrm{Si}\left[\mathrm{CH}_{3}\right]_{2}\right) . \mathrm{IR}\left(\mathrm{KBr}, \mathrm{cm}^{-1}\right)$ : 1655, $1562(\mathrm{~N}-\mathrm{C}=\mathrm{C}-\mathrm{C}=\mathrm{O})$. Anal. Calcd for $\mathrm{C}_{19} \mathrm{H}_{32} \mathrm{I}_{0.5} \mathrm{Li}_{0.5} \mathrm{~N}_{2} \mathrm{O}_{2} \mathrm{SSi}_{2}$ (5b.0.5Lil): C 47.98; H 6.78; N 5.89; Si 11.81. Found: C 47.86; H 6.71; N 5.93; $\mathrm{Si}$ 11.97. Minor isomer 5b': ${ }^{1} \mathrm{H}$ NMR $\left(\mathrm{C}_{6} \mathrm{D}_{6}\right): \delta 5.63(\mathrm{t}, J=5.9,1 \mathrm{H}, \mathrm{NH}) ; 4.28\left(\mathrm{~d}, J=5.9,2 \mathrm{H}, \mathrm{PhCH}_{2} \mathrm{~N}\right) ; 4.18(\mathrm{q}$, $\left.J=7.1,2 \mathrm{H}, \mathrm{OCH}_{2} \mathrm{CH}_{3}\right) ; 2.32\left(\mathrm{~s}, 3 \mathrm{H}, \mathrm{SCH}_{3}\right) ; 1.11\left(\mathrm{t}, J=7.2,3 \mathrm{H}, \mathrm{OCH}_{2} \mathrm{CH}_{3}\right) ; 0.69\left(\mathrm{~s}, 4 \mathrm{H}, \mathrm{SiCH}_{2} \mathrm{CH}_{2} \mathrm{Si}\right) ; 0.28$, $0.01\left(\mathrm{~s}, 12 \mathrm{H}, \mathrm{Si}\left[\mathrm{CH}_{3}\right]_{2}\right) .{ }^{13} \mathrm{C}$ NMR $\left(\mathrm{C}_{6} \mathrm{D}_{6}\right): \delta 169.9(\mathrm{C}=\mathrm{O}) ; 155.3(\mathrm{C}=\mathrm{C}[\mathrm{SMe}]) ; 138.7,129.0,127.8(\mathrm{Ph}-\mathrm{C})$; $107.2(\mathrm{C}=\mathrm{C}-\mathrm{COOEt}) ; 61.6\left(\mathrm{OCH}_{2} \mathrm{CH}_{3}\right) ; 48.8\left(\mathrm{PhCH}_{2} \mathrm{~N}\right) ; 20.1\left(\mathrm{SCH}_{3}\right) ; 14.4\left(\mathrm{OCH}_{2} \mathrm{CH}_{3}\right) ; 8.6\left(\mathrm{Si}-\mathrm{CH}_{2} \mathrm{CH}_{2} \mathrm{Si}\right)$; $1.4,0.8\left(\mathrm{Si}\left[\mathrm{CH}_{3}\right]_{2}\right)$.

Ethyl 2-(N,N-diethyl)amino-3-methylthio-3-(N-phenyl)aminopropenoate (5c): A solution of $0.87 \mathrm{~g}$ (2.35 mmol) of $2 \mathrm{c}$ and $0.35 \mathrm{~g}$ ( $2.5 \mathrm{mmol})$ of iodomethane in $25 \mathrm{ml}$ of THF was refluxed for $1 \mathrm{~h}$. By concentration of the resulting solution a yellow foam was obtained, which was dissolved in pentane, filtrated and concentrated to 
give a viscous yellow oil. This was shown to be $5 \mathrm{c}$, together with $6 \%$ of an isomeric compound. In the presence of $\mathrm{LiI}$ the oil solidified. Recrystallisation from $\mathrm{Et}_{2} \mathrm{O}$ /pentane (1:2) afforded $5 \mathrm{c} \bullet .5 \mathrm{LiI}$ as yellow crystals. Yield: 0.51 g (1.3 mmol, 55\%). Mp: $82{ }^{\circ} \mathrm{C}$. Major isomer 5c: ${ }^{1} \mathrm{H}$ NMR $\left(\mathrm{C}_{6} \mathrm{D}_{6}\right): \delta 9.53(\mathrm{~s}, 1 \mathrm{H}, \mathrm{NH}) ; 7.44(\mathrm{~d}, J=7.9,2 \mathrm{H}, o-$ $\mathrm{Ph}-\mathrm{H}) ; 7.05$ (dd, $J=7.3,7.9,2 \mathrm{H}, m-\mathrm{Ph}-\mathrm{H}) ; 6.79$ (t, $J=7.3,1 \mathrm{H}, \mathrm{p}-\mathrm{Ph}-\mathrm{H}) ; 4.34$ (q, $\left.J=7.1,2 \mathrm{H}, \mathrm{OCH}_{2} \mathrm{CH}_{3}\right) ; 2.98$ $\left.\left(\mathrm{q}, J=7.2,4 \mathrm{H}, \mathrm{N}\left[\mathrm{CH}_{2} \mathrm{CH}_{3}\right]_{2}\right) ; 1.62\left(\mathrm{~s}, 3 \mathrm{H}, \mathrm{SCH}_{3}\right) ; 1.24\left(\mathrm{t}, J=7.2,6 \mathrm{H}, \mathrm{N}^{2} \mathrm{CH}_{2} \mathrm{CH}_{3}\right]_{2}\right) ; 1.03(\mathrm{t}, J=7.2,3 \mathrm{H}$, $\left.\mathrm{OCH}_{2} \mathrm{CH}_{3}\right) .{ }^{13} \mathrm{C}$ NMR $\left(\mathrm{C}_{6} \mathrm{D}_{6}\right): \delta 168.6(\mathrm{C}=\mathrm{O}) ; 164.6(\mathrm{C}=\mathrm{C}$-SMe); 142.8, 129.3, 123.0, $121.2(\mathrm{Ph}-\mathrm{C}) ; 116.4$ $\left(\mathrm{MeS}-\mathrm{C}=\mathrm{C}\right.$-); $\left.\left.61.9\left(\mathrm{OCH}_{2} \mathrm{CH}_{3}\right) ; 48.6\left(\mathrm{~N}_{\left[\mathrm{CH}_{2}\right.} \mathrm{CH}_{3}\right]_{2}\right) ; 15.5\left(\mathrm{OCH}_{2} \mathrm{CH}_{3}\right) ; 14.3\left(\mathrm{SCH}_{3}\right) ; 14.2\left(\mathrm{~N}_{2} \mathrm{CH}_{2} \mathrm{CH}_{3}\right]_{2}\right)$ IR $\left(\mathrm{KBr}, \mathrm{cm}^{-1}\right)$ : 1647, 1599 (N-C=C-C=O). Anal. Calcd for $\mathrm{C}_{16} \mathrm{H}_{24} \mathrm{I}_{0.5} \mathrm{Li}_{0.5} \mathrm{~N}_{2} \mathrm{O}_{2} \mathrm{~S}$ (MW: 375.37): C 51.20; $\mathrm{H}$ 6.44; I 16.90; N 7.46. Found: C 51.62; H 6.23; I 17.16; N 7.50. Minor isomer 5c': ${ }^{1} \mathrm{H}$ NMR $\left(\mathrm{C}_{6} \mathrm{D}_{6}\right): \delta 8.38$ (s, $1 \mathrm{H}, \mathrm{NH}) ; 4.30\left(\mathrm{q}, J=7.1,2 \mathrm{H}, \mathrm{OCH}_{2} \mathrm{CH}_{3}\right) ; 2.79\left(\mathrm{q}, J=7.2,4 \mathrm{H}, \mathrm{N}\left[\mathrm{CH}_{2} \mathrm{CH}_{3}\right]_{2}\right) ; 1.93\left(\mathrm{~s}, 3 \mathrm{H}, \mathrm{SCH}_{3}\right) ; 0.91(\mathrm{t}, J=$ 7.2, 3H, $\left.\mathrm{OCH}_{2} \mathrm{CH}_{3}\right) .{ }^{13} \mathrm{C}$ NMR $\left(\mathrm{C}_{6} \mathrm{D}_{6}\right): \delta 164.6(\mathrm{C}=\mathrm{C}$-SMe); 142.0, 129.5, 124.1, $122.4(\mathrm{Ph}-\mathrm{C}) ; 61.9$ $\left(\mathrm{OCH}_{2} \mathrm{CH}_{3}\right) ; 48.5\left(\mathrm{~N}\left[\mathrm{CH}_{2} \mathrm{CH}_{3}\right]_{2}\right) ; 16.9\left(\mathrm{OCH}_{2} \mathrm{CH}_{3}\right) ; 14.6\left(\mathrm{SCH}_{3}\right) ; 14.2\left(\mathrm{~N}\left[\mathrm{CH}_{2} \mathrm{CH}_{3}\right]_{2}\right)$.

Acknowledgement: The authors wish to thank Gist-brocades for financially supporting this research. Dr. J. Verweij and dr. A.P.G. Kieboom are kindly acknowledged for their stimulating discussions. This work wa: supported in part (A.L.S., H.K.) by the Netherlands Foundation of Chemical Research (SON) with financial aid from the Netherlands Foundation for Scientific Research (NWO). X-ray data were kindly collected by A.J.M. Duisenberg.

\section{References and Notes:}

1. For examples of total synthesis of penicillin derivatives, see: a: Sheehan, J.C.; Henery-Logan, K.R., J. Am. Chem. Soc. 1957, 79, 1262-1263; b: Firestone, R.A.; Maciejewicz, N.S.; Christensen, B.G., J. Org. Chem. 1974, 39, 3384-3387; c. Nakatsuka, S.; Tanino, H.; Kishi, Y.,J. Am. Chem Soc. 1975, 97, 5008-5010; d: Baldwin, J.E.; Christie, M.A.; Haber, S.B.; Kruse, L., J. Am. Chem. Soc. 1976, 98, 3045-3047; e. Barrett, A.G.M.; Sakadarat, S., J. Org. Chem. 1990, 55, 5110-5117.

2. Verweij, J.; De Vroom, E., Recl. Trav. Chim. Pays-Bas 1993, 112, 66-81.

3. Staudinger, H., Annalen, 1907, 356, 51-123.

4. a: Sheehan, J.C., Ryan, J.J., J. Am. Chem. Soc. 1951, 73, 1204-1207; b: Mukcrjee, A.K.; Singh, A.K., Tetrahedron, 1978, 34, 1731-1767; c: "Chemistry and Biology of $\beta$-Lactam Antibiotics"; Ed.: Morin, R.B.; Gorman, M; Acad. Press, New York, 1982, vol. 1-3; d: Govindachari, T.R.; Chinnasamy, P.; Raewari. S.; Candrasekaran, S.; Premila, M.S.; Nagarajan, K.; Pai, .R.; Heterocycles 1984, 22, 585; e. Evans, D.A.; Sjögren, E.B.; Tetrahedron Lett. 1985, 26, 3783-3786; f: Cooper, R.D.G.; Daugherty, B.W.; Boyd, D.B.; Pure \& Appl. Chem. 1987, 59, 485-492; g: Shandu, J.S.; Sain, B.; Heterocycles 1987, 26, 777; ' : Palomo, C.; Cossio, F.P.; Cuevas, C.; Lecea, B.; Mielgo, A.; Roman, P.; Luque, A.; Martinez-Ripoll, M.; J. Am. Chem. Soc. 1992, 114,9360-9369.

5. a: Paul, L.; Dräger, A.; Hilgetag, G., Chem. Ber. 1966, 99, 1957-1961; b: Bose, A.K.; Spiegelman, G.; 
Manhas, M.S., J. Am. Chem. Soc. 1968, 90, 4506-4508; c: Bachi, M.D.; Rothfield, M., J. Chem. Soc., Perkin Trans. I 1972, 2326-2331; d: Bachi, M.; Goldberg, O., J. Chem. Soc., Perkin Trans. I 1972, 23322336; ': Lattrell, R.; Lohaus, G., Liebigs Ann. Chem. 1974, 870-900.

6. Trans-substituted intermediates were partially epimerized to cis- $\beta$-lactams by deprotonation followed by protonation under kinetic conditions: Firestone, R.A.; Maciejewicz, N.S.; Ratcliffe, R.W.; Christensen, B.G., J. Org. Chem. 1974, 39, 437-440.

7. For recent reviews, see: a: Hart, D.J.; Ha, D-C., Chem. Rev. 1989, 89, 1447-1465; b: Brown, M.J., Heterocycles 1989, 29, 2225-2244; c. Van der Steen, F.H.; Van Koten, G., Tetrahedron 1991, 47, 75037524.

8. a: Chou, T.S.; Koppel, G.A.; Dorman, D.E.; Paschal, J., J. Am. Chem. Soc. 1976, 98, 7864-7865; b: Bachi, M.D.; Goldberg, O. Gross, A.; Vaya, J.,J. Org. Chem. 1980, 45, 1477-1480.

9. Brandt, A.; Bassignani, L.; Re, L., Tetrahedron Lett. 1976, 17, 3975-3978.

10. a: Bachi, M.D.; Goldherg, O.;Gross, A., Tetrahedron Lett. 1978, 19, 4167-4170; b: Bachi, M.D.; Goldberg, O.; Gross, A.; Vaya, J.,J. Org. Chem. 1980, 45, 1481-1485.

11. Aoyama, H.; Sagae, H.; Hosomi, A., Tetrahedron Lett. 1993, 34, 5951-5952.

12. Schauman, E.; Röhr, A.; Adiwidjaja, G., Tetrahedron Lett. 1980, 21, 4247-4250.

13. Sakamoto, M.; Tanaka, M.; Fukuda, A.; Aoyama, H.; Omote, Y., J. Chem. Soc., Perkin Trans. I 1988, 1353-1355.

14. Cainelli, G.; Giacomini, D.; Panunzio, M.; Martelli, G. Spunta, G., Tetrahedron Lett. 1987, 28, 3593-3596.

15. Dürckheimer, W.; Blumbach, J.; Latirell, R.; Scheunemann, K.H.,Angew. Chem. 1985, 97, 183-205.

16. a: Van der Steen, F.H.; Kleijn, H.; Spek, A.L.; Van Koten, G., J. Chem. Soc., Chem. Commun. 1990, 503504; b: Van der Steen, F.H.; Kleijn, H.; Jastrzebski, J.T.B.H.; Van Koten, G., J. Org.Chem 1991, 56, 5147. 5158; c: Van der Steen, F.H.; Van Mier, G.P.M.; Spek, A.L.; Kroon, J.; Van Koten, G., J. Am. Chem. Soc. 1991, 113, 5742-5750; d: Van der Steen, F.H.; Kleijn, H.; Britovsek, G.J.P.; Jastrzebski, J.T.B.H.; Van Koten, G., J. Org. Chem. 1992, 57, 3906-3916; e. Van der Steen, F.H.; Boersma, J.; Spek, A.L.; Van Koten, G., Organometallics 1991, 10, 2467-2480; f: Van Maanen, H.L.; Jastrzebski, J.T.B.H.; Verweij, J.; Kieboom, A.P.G.; Spek, A.L.; Van Koten, G., Tetrahedron Asymm. 1993, 4, 1441-1444.

17. STABASE as protecting group: Djuric, S.; Venit, J.; Magnus, P., Tetrahedron Lett. 1981, 22, 1787-1790.

18. The analogous reaction of trimethylsilyl isothiocyanate did not afford any C-C coupled product. Instead, the $(E)$-TMS ketene acetal $16 e$ of $1 \mathrm{a}$ was obtained in a high yield (89 \%).

19. Krapcho, A.P.; Stephens, W.P.,J. Org. Chem. 1980, 45, 1106-1109.

20. Sullivan, D.F.; Woodbury, R.P.; Rathke, M.W.,J. Org. Chem. 1977, 42, 2038-2039.

21. a: Shea, K.J.; Gobeille, R.; Bramblett, J.: Thompson, E., J. Am. Chem. Soc. 1978, 100, 1611-1613; b: Bernardi, F.; Bongini, A.; Cainelli, G.; Robb, M.A.; Suzzi Valli, G.;J. Org. Chem. 1993, 58, 750-755.

22. Galigné, J.L.; Mouvet, M.; Falgueirettes, J., Acta Cryst. 1970, B26, 368-372.

23. Schröder, F.A.; Weber, H.P.,Acta Cryst. 1975, B31, 1745-1750.

24. Williard, P.G.; Salvino, J.M.,Tetrahedron Lett. 1985, 26, 3931-3934.

25. a: Seebach, D.; Amstutz, R.; Laube, T.; Schweizer, W.B.; Dunitz, J.B., J. Am. Chem. Soc. 1985, 107, 54035409; b: Seebach, D., Angew. Chem. 1988, 100, 1685-1715.

26. Cambilleau, C.; Bram, G.; Corset, J.; Riche, C., Can. J. Chem. 1982, 60, 2554-2565.

27. a: Banister, A.J.; Clegg, W.; Gill, W.R., J. Chem. Soc., Chem. Commun. 1987, 850-852; b: Sigel, G.A.; Power, P.P., Inorg. Chem. 1987, 26, 2819-2822; c. Janssen, M.D.; Spek, A.L.; Grove, D.M.; Van Koten, G., 
manuscript in preparation; d: Janssen, M.D.; De Wolf, C.; Hogerheide, M.P.; Spek, A.L.; Grove, D.M.;

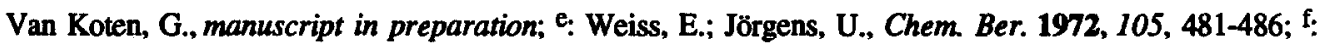
Aslam, M.; Bartlett, R.A.; Block, E.; Olmstead, M.M.; Power, P.P.; Sigel, G.A., J. Chem. Soc., Chem. Commun. 1985, 1674-1675; Armstrong, D.R.; Banister, A.J.; Clegg, W.; Gill, W.R.,J. Chem. Soc., Chem. Commun. 1986, 1672-1673.

28. $\mathrm{Me}_{2} \mathrm{Al}(\mathrm{acac})$ and related compounds are monomeric: a: Kroll, W.R.; Năgele, W., J. Organomet. Chem. 1969, 19, 439-443; b: Kroll, W.R.; Kuntz, I.; Birnbaum, E., J. Organomet. Chem. 1971, 26, 313-320.

29. a: Kobayashi, K.; Sumitomo, H.; Hashimoto, K.; Kato, Y., J. Organomet. Chem. 1973, 49, C1-C2; b: Van Vliet, M.R.P.; Van Koten, G.; Modder, J.F.; Van Beek, J.A.M.; Klaver, W.J.; Goubitz, K.; Stam, C.H., J. Organomet. Chem. 1987, 319, 285-301.

30. Simple enethiols have been found to be thermodynamically stable with respect to tautomerisation to the corresponding thioketones: Le Nocher, A-M.; Metzner, P., Tetrahedron Lett. 1992, 33, 651-654.

31. Carlsson, S.; Lawesson, S.-O., Tetrahedron 1982, 38, 413-417.

32. Barnikow, G.; Kunzek, H., Liebigs Ann. Chem. 1966, 700, 36-45.

33. Desulphurisation of thioamides with $\mathrm{NaBH}_{4}$ has been accomplished via alkylthio-iminium salts. a: Raucher, S.; Klein, P., Tetrahedron Lett. 1980, 21, 4061-4064; b: Sundberg, R.J.; Powers Walters, C.; Bloom, D., J. Org. Chem. 1981, 46, 3730-3732.

34. a: Woodward, R.B.; Heusler, K.; Gosteli, J.; Năgeli, P.; Oppolzer, W.; Ramage, R.; Ranganathan, S.; Vorbrüggen, H., J. Am. Chem. Soc. 1966, 88, 852-853; b: Cainelli, G.; Contento, M.; Drusiani, A.; Panunzio, M.; Plessi, L., J. Chem. Soc., Chem. Cmmun. 1985, 240; c. Vorbrüggen, H.; Woodward, R.B., Tetrahedron 1993,49, 1625-1634.

35. For a review, see: Walter, W.; Bode, K.-D.,Angew. Chem. 1966, 78, 517-532.

36. a: Worrall, D.E., J. Am Chem. Soc. 1918, 40, 415-423; b: Worrall, D.E., J. Am Chem. Soc. 1928, 50, 14561459.

37. a: Greenhill, J.V., Chem. Soc. Rev. 1977, 6, 277-294; b. Melillo, D.G.; Cvetovich, R.J.; Ryan, K.M.; Sletzinger, M., J. Org. Chem. 1986, 51, 1498-1504; c. Elghandour, A.H.H.; Ramiz, M.M.M.; Elnagdi, M.H., Synthesis 1989, 775-777; d: Guingant, A., Tetrahedron Asymm. 1991, 2, 415-418; e. Fustero, S.; Díaz, D.; Barluenga, J.; Aguilar, E., Tetrahedron Lett. 1992, 33, 3801-3804; f: Fustero, S.; Díaz, D.; Pérez, C.R., Tetrahedron Lett. 1993, 34, 725-728; g: Friary, R.J.; Seidl, V.; Schwerdt, J.H.; Cohen, M.P.; Hou, D.; Nafissi, M., Tetrahedron 1993, 49, 7169-7178; h. Friary, R.J.; Seidl, V.; Schwerdt, J.H.; Chan, T-M.; Cohen, M.P.; Conklin, E.R.; Duelfer, T.; Hou, D.; Nafissi, M.; Runkle, R.L.; Tahbaz, P.; Tiberi, R.L.; McPhail, A.T., Tetrahedron 1993, 49, 7179-7192.

38. Datta, A.; Ila, H.; Junjappa, H., Synthesis 1988, 248-250.

39. Hamilton, R.T.; Butler, J.A.V.,J. Chem. Soc. 1932, 2283-2284.

40. Spek, A.L., J. Appl. Crystallogr. 1988, 21, 578-579

41. Sheldrick, G.M. SHELXS86 Program for crystal structure determination. University of Göttingen, Germany, 1986.

42. Sheldrick, G.M. SHELX76 Program for crystal structure determination. University of Cambridge, Cambridge, 1976.

43. Cromer, D.T.; Mann, J.B., Acta Crystallogr. 1968, A24, 321-324.

44. Cromer, D.T.; Liberman, D.,J. Chem. Phys. 1970, 53, 1891-1898.

45. Spek, A.L., Acta Crystallogr. 1990, A46, C34. 